\title{
Contaminated Nickel Scrap Processing
}
A. L. Compere
W. L. Griffith
H. W. Hayden
J. S. Johnson, Jr.
D. F. Wilson

\section{MAMAGED by}

MARTIN WARIETTA ENERGY SYSTEWS, INC.

FOR THE UNITED STATES

DEPARTIENT OF ENERGY

\section{MASTER}


This report has been reproduced directly from the best available copy.

Available to DOE and DOE contractors from the Office of Scientific and Technical Information, P.O. Box 62, Oak Ridge, TN 37831; prices available from (615) 576-8401, FTS 626-8401.

Available to the public from the National Technical Information Service, U.S. Department of Commerce, 5285 Port Royal Rd., Springfield, VA 22161.

This report was prepared as an account of work sponsored by an agency of the United States Government. Neither the United States Government nor any agency thereof, nor any of their employees, makes any warranty, express or implied, or assumes any legal liability or responsibility for the accuracy, completeness, or usefulness of any information, apparatus, product, or process disclosed, or represents that its use would not infringe privately owned rights. Reference herein to any specific commercial product, process, or service by trade name, trademark, manufacturer, or otherwise, does not necessarily constitute or imply its endorsement, recommendation, or favoring by the United States Government or any agency thereof. The views and opinions of authors expressed herein do not necessarily state or reflect those of the United States Government or any agency thereof. 


\section{DISCLAIMER}

Portions of this document may be illegible in electronic image products. Images are produced from the best available original document. 


\title{
Contaminated Nickel Scrap Processing
}

\author{
A. L. Compere \\ W. L. Griffith \\ H. W. Hayden \\ J. S. Johnson, Jr. \\ D. F. Wilson
}

Prepared by the Oak Ridge National Laboratory

Oak Ridge, Tennessee 37831 managed by

Martin Marietta Energy Systems, Inc.

for the

U. S. Department of Energy

under Contract No. DE-AC05-84OR21400

Date Published: December 1994

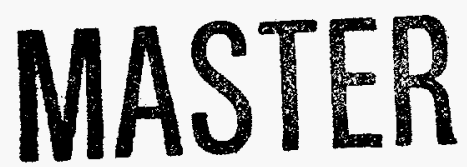





\section{Contents}

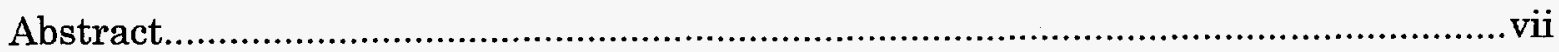

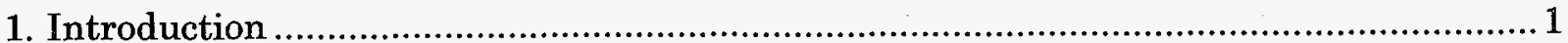

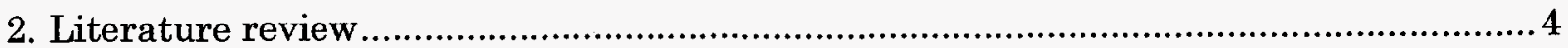

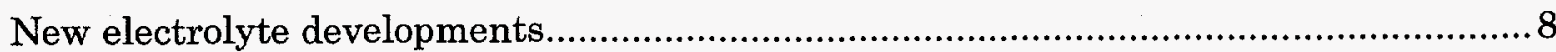

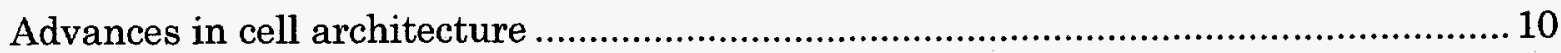

Advances in separator materials .............................................................. 12

Contaminant separation processes ............................................................... 13

Advanced integrated process development................................................... 19

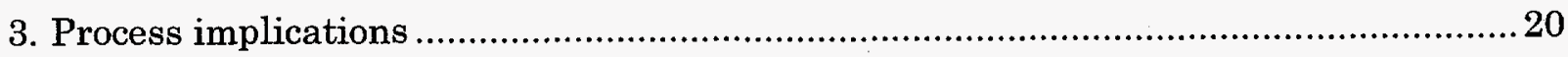

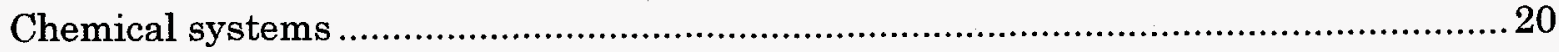

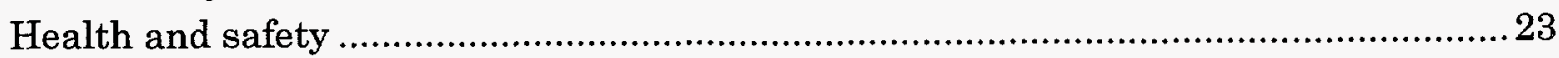

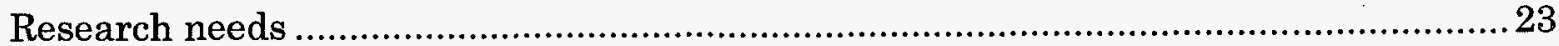

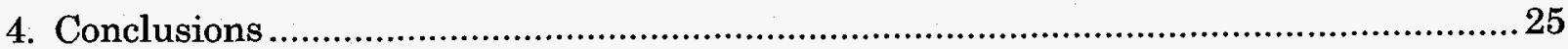

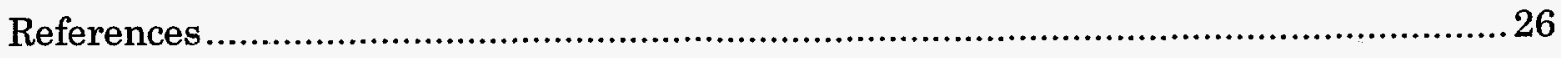




\section{Tables}

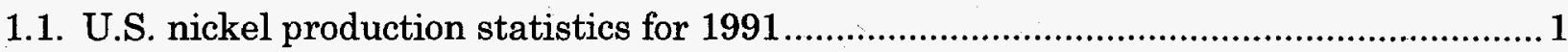

2.1. Standard electrode potentials of selected nickel refining reactions $\left(77^{\circ} \mathrm{C}\right) \ldots \ldots \ldots \ldots \ldots . . . . . .7$

2.2. Electrolyte for conventional nickel electrorefining.............................................. 10

2.3 Technetium extraction from industrial (acid) nitrate solutions ............................... 17

2.4 Advanced nickel decontamination processes ................................................ 19 


\section{Figures}

1.1. Schematic operation of conventional nickel electrorefining cell ................................2

2.1. Production of nickel by the carbonyl process.......................................................5

2.2. Ammonia leach/direct hydrogen reduction process ...........................................6

2.3. Nickel electrorefining from matte................................................................. 8

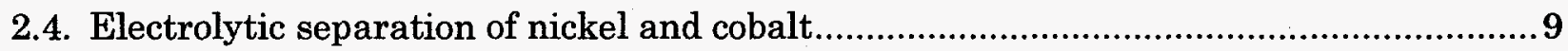

2.5 Falconbridge Nickel Refinery chlorine-based process .......................................... 11 



\title{
Contaminated Nickel Scrap Processing*
}

\author{
A. L. Compere \\ W. L. Griffith \\ H. W. Hayden \\ J. S. Johnson, Jr. \\ D. F. Wilson
}

\begin{abstract}
The DOE will soon choose between treating contaminated nickel scrap as a legacy waste and developing high-volume nickel decontamination processes. In addition to reducing the volume of legacy wastes, a decontamination process could make 200,000 tons of this strategic metal available for domestic use. Contaminants in DOE nickel scrap include ${ }^{234} \mathrm{Th},{ }^{234} \mathrm{~Pa},{ }^{137} \mathrm{Cs},{ }^{239} \mathrm{Pu}$ (trace), ${ }^{60} \mathrm{Co}, \mathrm{U},{ }^{99} \mathrm{Tc}$, and ${ }^{237} \mathrm{~Np}$ (trace). This report reviews several industrial-scale processes - electrorefining, electrowinning, vapometallurgy, and leaching - used for the purification of nickel. Conventional nickel electrolysis processes are particularly attractive because they use side-stream purification of process solutions to improve the purity of nickel metal. Additionally, nickel purification by electrolysis is effective in a variety of electrolyte systems, including sulfate, chloride, and nitrate. Conventional electrorefining processes typically use a mixed electrolyte which includes sulfate, chloride, and borate. The use of an electrorefining or electrowinning system for scrap nickel recovery could be combined effectively with a variety of processes, including cementation, solvent extraction, ion exchange, complex-formation, and surface sorption, developed for uranium and transuranic purification. Selected processes were reviewed and evaluated for use in nickel side-stream purification.
\end{abstract}

*Research sponsored by the Office of Technology Development, U. S. Department of Energy, under contract DE-AC05-84OR21400 with Martin Marietta Energy Systems, Inc. 


\section{Introduction}

This report presents an evaluation of selected technologies which could provide a basis for development of processes for recovering nickel values from $\mathrm{DOE}$-produced scrap. $\mathrm{DOE}$ nickel scrap typically contains small amounts of uranium and trace quantities of cobalt and uranium daughter products. This study was performed early in the project to facilitate process development and to identify areas where research is needed. The DOE is interested in recovery of radiologically contaminated nickel from the perspectives of minimzation of legacy wastes and of strateegic materials conservation.

Nickel is a relatively scarce, expensive, strategic metal purchased from a variety of foreign sources, most prominently Canada, Norway, and Australia. Its resistance to $\mathrm{HF}$ and $\mathrm{UF}_{6}$ have made nickel and nickel alloys ubiquitous in a variety of nuclear applications.

Development of an effective nickel purification process could make 200,000 tons, or nearly $\$ 1$ billion, of nickel available from decommissioning the first generation gaseous diffusion plants. As may be inferred from Table 1.1, the nickel potentially available from gaseous diffusion plant decommissioning is equivalent to roughly 3 decades of domestic production, 6 years of recycle, or 17 months of imports.

Although nickel is potentially valuable, its purification is technically demanding. In the DOE system, nickel scrap comes from a variety of sources, including gaseous diffusion

Table 1.1. U.S. nickel production statistics for 1991

\begin{tabular}{lc}
\hline Item & Amount, tonnes \\
\hline Nickel production & 7,065 \\
Recovery from ferrous and non-ferrous scrap & 32,520 \\
Apparent consumption & 137,199 \\
Nickel imports & 138,657 \\
Nickel exports & 36,902 \\
\hline
\end{tabular}

Source: Kuck 1991. plants and reactor containment steels.

Radioactive contaminants in this scrap include: ${ }^{234} \mathrm{Th},{ }^{234} \mathrm{~Pa}$, ${ }^{137} \mathrm{Cs},{ }^{239} \mathrm{Pu}$ (trace), ${ }^{60} \mathrm{Co}, \mathrm{U}$, ${ }^{99} \mathrm{Tc}$, and ${ }^{237} \mathrm{~Np}$ (trace). Present DOE standards for public resale require the absence of contaminants. However, standards for reuse within the DOE system are

less restrictive and recycled nickel and its alloys could replace a substantial volume of current purchases. If an effective recovery-recycle process is developed, operating experience may permit development of less-restrictive future standards for public resale.

The high volume of DOE scrap encourages the development of a process which uses conventional large-scale nickel purification equipment. Electrorefining and electrowinning, as described by Boldt (1967) are most commonly used for nickel refining. A typical industrial scale electrorefining cell is shown in Figure 1.1. In electrorefining, an impure nickel anode is dissolved into the anolyte (liquid adjacent to the anode) which is subsequently removed from the cell and treated to decrease selected impurities. After treatment, the liquid is reintroduced at the cathode as catholyte. Catholyte purity is maintained by positive pressure through a canvas bag surrounding the cathode. Nickel ions are electrolytically deposited on the cathode. Electrowinning may employ either dissolving anodes of nickel salts, typically nickel sulfide, or the combination of insoluble anodes and dissolved nickel. 


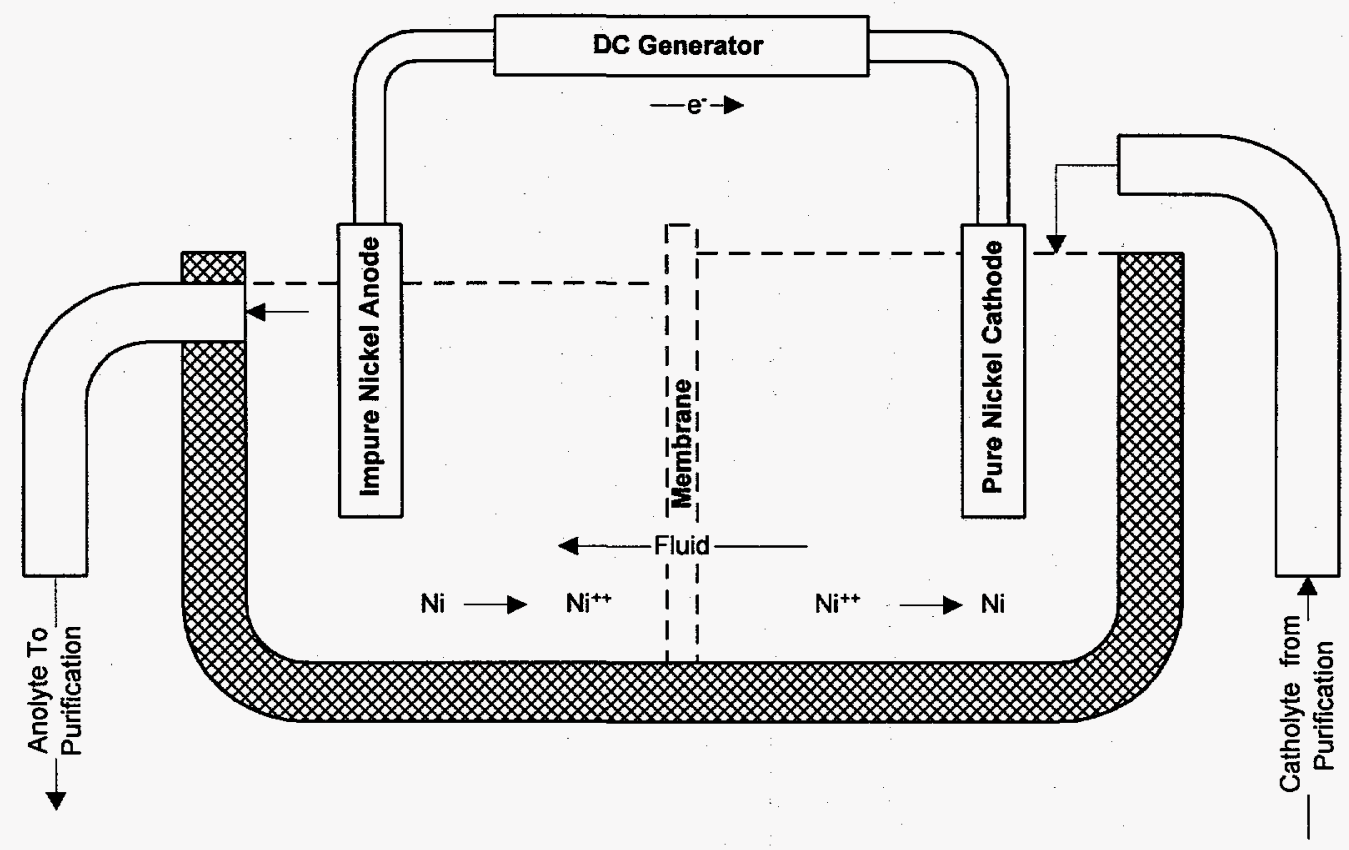

Fig. 1.1. Schematic operation of conventional nickel electrorefining cell. Modified from: Boldt 1967.

Two other processes for nickel purification, vapometallurgy and leacing, are also used at industrial scale. In vapometallurgy, nickel carbonyl formed from reaction of nickel powder and and carbon monoxide is decomposed to yield pure nickel. A related process scheme involves ammonia leaching and reduction to form nickel.

Both processes for nickel production by electrolysis are attractive for DOE operations because they provide opportunities to use sidestream processing to remove the contaminants specific to a given lot of scrap. This could maximize process flexibility while minimizing installed capital cost.

Nickel, nickel alloys, and high-nickel steels have historically been used in a wide variety of nuclear process equipment. As facilities are decommissioned, these materials become scrap. The processes discussed in this report are focused on a limited number of nickel products. Different types of nickel-bearing scrap will require other types of processing. Where the nickel is relatively impure or where it is an alloy constituent, conventional practice typically employs successive electrowinning and electrorefining steps. The new molten metal process might also be employed as a first step to separate materials more chemically active than nickel. Where scrap is surface contaminated, washing or leaching is likely to be more appropriate.

Chemical operations of the conventional nickel refining processeswill have to be modified to improve removal of the contaminants particular to DOE operations and to meet DOE radiological safety requirements. Conventional systems, for example, typically use a complex electrolyte which contains buffers, such as borate, and salts added to increase current density. Impurities are generally present at levels ranging from 0.01 (lead) to $4 \%$ 
(copper). These impurities are typically removed by precipitation or cementation. High purity, or $99.9 \%$ nickel still contains $0.1 \%$, or 1 gram per $\mathrm{kg}$ of impurities. This level would be unacceptably high for the radioactive contaminants in DOE scrap.

To reach very low levels, perhaps less than $1 \mathrm{mg}$ per $\mathrm{kg}$, of contaminants, highly selective modern separations processes can be used in conjunction with less selective, but less expensive, conventional separations. For the radionuclides of interest, selective separations will typically include ion exchange and solvent extraction. In order to permit these separations to operate effectively, process electrolyte concentration will have to be simplified and modified. Otherwise, the electrolyte anions themselves could interfere with the separation. Thus, both sidestream processes and the working electrolyte will have to be reoptimized. The goal is a working electrolyte with a single predominant anion which will produce acceptable electrorefining rates at $\mathrm{pH}$ conditions which facilitate separations.

Some changes in operating hardware are likely to be required. For example, industrial electrorefining processes like those shown in Fig. 1.1, are typically wood or concrete tanks lined with non-conductive asphalt. Canvas bags are used to contain the catholyte and to provide a slight positive pressure into the electrolyte. In any process which involves radioisotopes, leak prevention and ease of decontamination will drive the choice of tank and membrane materials toward modern, high performance polymers. Any electolytic processing facility constructed de novo will be expected to reflect improvements in cell design, materials, membranes, and control systems found in current research and operation.

This report is an evaluation of nickel refining and separations processes which, in conjunction, could be used to recover both nickel and radioisotopes from gaseous diffusion plant scrap. A literature review and an evaluation of possible unit processes. These materials will be used to develop process concepts for bench-scale evaluation. 


\section{Literature Review}

To produce pure, high quality nickel from a wide variety of industrial feedstocks has required develpment of a variety of innovative refining technologies tailored to the feedstock and to the qualities and types of nickel required by the marketplace (Boldt 1967, Tien and Howson 1981). The elements that are removed during refining include antimony, arsenic, bismuth, cobalt, copper, iron, lead, phosphorous, sulfur, tin, and zinc. The removal of cobalt is especially important in materials used in the nuclear industry, since the bombardment of cobalt by neutrons produces a highly radioactive isotope, ${ }^{60} \mathrm{Co}$, with a half life of approximately 5 years.

Nickel refining practices vary considerably. Refining via electrolysis has been performed using solid anodes of impure nickel metal in a process called electrorefining and using an impure liquid nickel solution or impure nickel sulfide in a process called electrowinning. Additionally, carbonyl (or vapometallurgy) and an ammonia leach/direct hydrogen reduction processes are used at industrial scale. The process used by the Copper Cliff plant to recover nickel by vapometallurgy is detailed in Fig. 2.1. In a typical carbonyl process, impure nickel oxide is reduced to metal with hydrogen; the impure nickel is reacted $\left(50-100^{\circ} \mathrm{C}\right)$ with carbon monoxide to produce gaseous nickel carbonyl, $\mathrm{Ni}(\mathrm{CO})_{4}$; the gas, in turn, is thermally decomposed $\left(180-300^{\circ} \mathrm{C}\right)$ to yield pure nickel.

In the ammonia leach/direct hydrogen reduction process, an ammonia leach is employed at high temperature and pressure to dissolve the impure nickel; direct hydrogen reduction of the solution produces nickel in a powder form. The process used by the Fort Saskatchewan hydrometallurgical plant is shown in Fig. 2.2. Ammonia leaching has the advantages of increasing product recovery while reducing process complexity.

The underlying principles of nickel electrolysis are the same for both electrorefining and electrowinning. However, there is a fundamental difference - in electrorefining there is no net cell reaction, whereas in electrowinning there is a net cell reaction.

In electrorefining, the cell consists of an anode of impure nickel and a thin "starting sheet" cathode of pure nickel immersed in an electrolyte, a conducting aqueous solution. As current flows from the anode to the cathode in the external circuit, the nickel and some impurities dissolve from the anode into the surrounding solution, the anolyte. Anolyte is removed from the cell, chemically cleaned of impurities, and returned to the cell around the cathode as catholyte. Impure anolyte is prevented from coming in direct contact with the cathode by means of a porous diaphragm. Nickel from the catholyte is then deposited on the cathode. This completes the electrical circuit of the cell. The overall reaction at the anode can be written as:

$$
\mathrm{Ni} \rightarrow \mathrm{Ni}^{++}+2 \mathrm{e}^{-}
$$

And the overall reaction at the cathode can be written as:

$$
\mathrm{Ni}^{++}+2 \mathrm{e}^{-} \rightarrow \mathrm{Ni}
$$




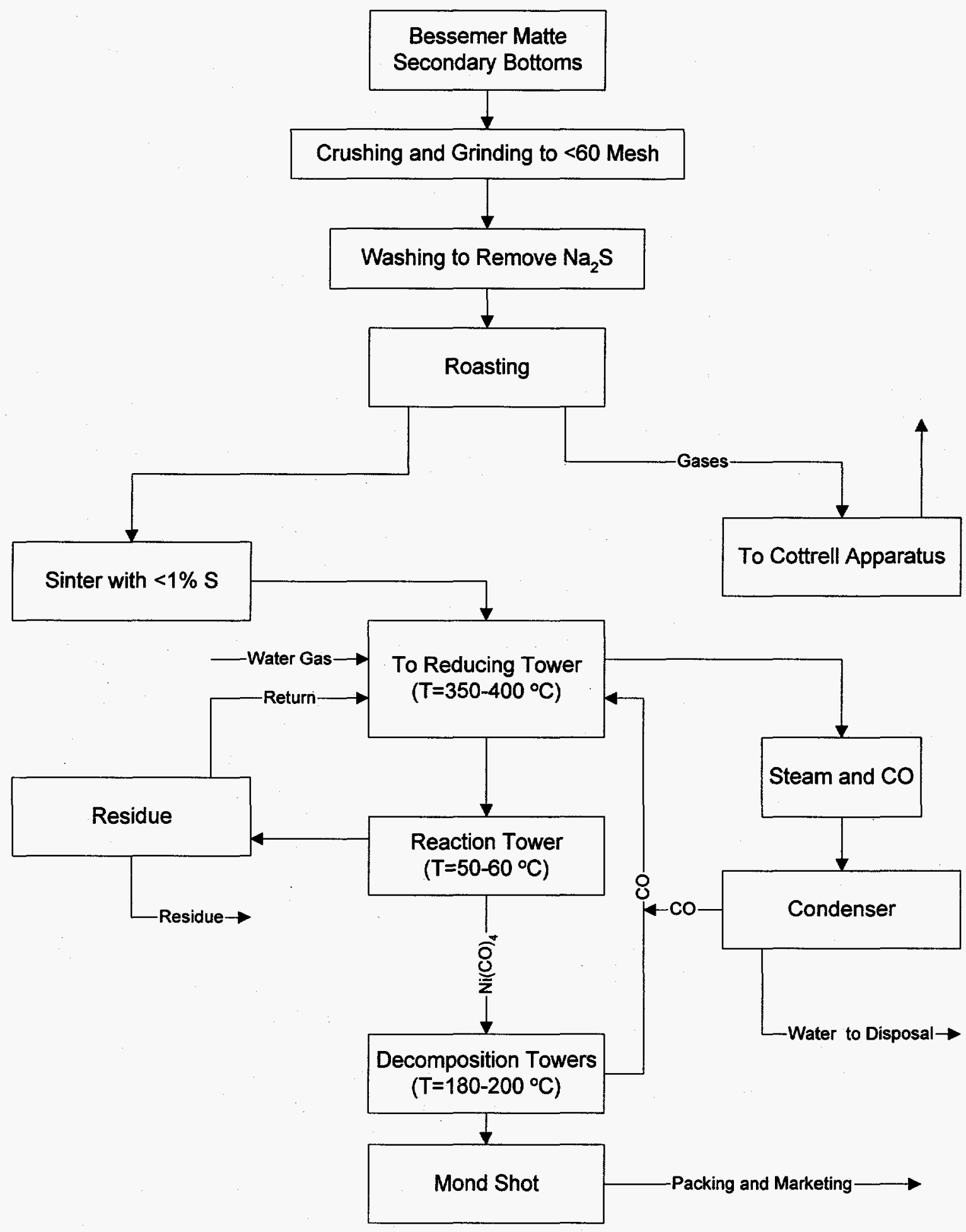

Fig. 2.1. Production of nickel by the carbonyl process. Adapted from Kornilov 1963. 


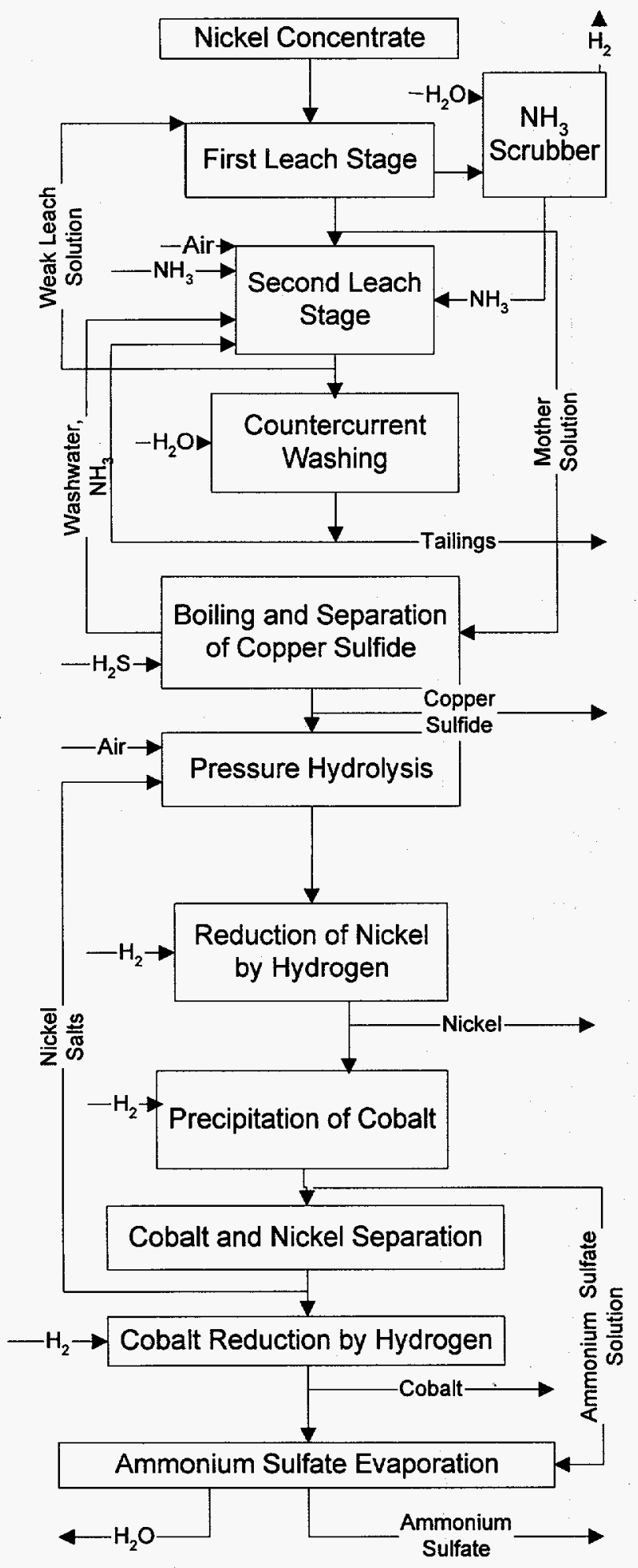

Fig 2.2. Ammonia leach/direct hydrogen reduction process. Adapted from Kornilov 1963.
The net cell reaction is zero, a characteristic of any electrorefining process. It must be noted that not all the current through the cell is used to refine nickel, since other anodic and cathodic reactions may be occurring at the same time.

The electrode potential of a reaction is the sum of three components - reversible potential, concentration polarization potential, and activation potential. The electrochemical series of reversible potentials for reactions generally occurring during nickel refining are presented in Table 2.1. The more negative the potential, the more readily the anodic reaction occurs, and the more positive the potential, the more readily the cathodic reaction occurs.

A typical process flow diagram for recovery of nickel, cobalt, and precious metals from matte is shown in Fig. 2.3. At the normal operating voltage of the electrorefining system, cobalt, iron, lead, zinc, and arsenic go into solution with the nickel. The platinum group, silver, and gold, and the metalloids sulfur, selenium, and tellurium do not dissolve. As the anode dissolves, most of the insolubles fall to the bottom of the tank and are referred to as slime. The anolyte is passed through a chemical purification process to remove the impurities. Copper is usually removed by cementation with metallic nickel which causes copper ions to precipitate in metallic form and nickel atoms to go into solution:

$$
\mathrm{Ni}+\mathrm{Cu}^{++} \rightarrow \mathrm{Cu}+\mathrm{Ni}^{++}
$$

Copper may also be removed by hydrogen sulfide which causes copper to precipitate as copper sulfide:

$$
\mathrm{Cu}^{++}+\mathrm{H}_{2} \mathrm{~S} \rightarrow \mathrm{CuS}+2 \mathrm{H}^{+}
$$


Table 2.1. Standard electrode potentials of selected nickel refining reactions $\left(77^{\circ} \mathrm{C}\right)$

\begin{tabular}{llc}
\hline Element & Reversible Reaction & Reversible Potential (V) \\
\hline Sodium & $\mathrm{Na} \leftrightarrow \mathrm{Na}^{+}+\mathrm{e}^{-}$ & -2.71 \\
Zinc & $\mathrm{Zn} \leftrightarrow \mathrm{Zn}^{++}+2 \mathrm{e}^{-}$ & -0.76 \\
Iron & $\mathrm{Fe} \leftrightarrow \mathrm{Fe}^{++}+2 \mathrm{e}^{-}$ & -0.44 \\
Cobalt & $\mathrm{Co} \leftrightarrow \mathrm{Co}^{++}+2 \mathrm{e}^{-}$ & -0.28 \\
Nickel & $\mathrm{Ni} \leftrightarrow \mathrm{Ni}^{++}+2 \mathrm{e}^{-}$ & -0.25 \\
Lead & $\mathrm{Pb} \leftrightarrow \mathrm{Pb}^{++}+2 \mathrm{e}^{-}$ & -0.13 \\
Hydrogen & $\mathrm{H} \leftrightarrow 2 \mathrm{H}^{+}+2 \mathrm{e}^{-}$ & 0.00 \\
Copper & $\mathrm{Cu} \leftrightarrow \mathrm{Cu}^{++}+2 \mathrm{e}^{-}$ & +0.34 \\
& $\mathrm{Cu} \leftrightarrow \mathrm{Cu}^{+}+\mathrm{e}^{-}$ & +0.52 \\
Silver & $\mathrm{Ag} \leftrightarrow \mathrm{Ag}^{+}+\mathrm{e}^{-}$ & +0.80 \\
Palladium & $\mathrm{Pd} \leftrightarrow \mathrm{Pd}^{++}+2 \mathrm{e}^{-}$ & +0.99 \\
Platinum & $\mathrm{Pt} \leftrightarrow \mathrm{Pt}^{++}+2 \mathrm{e}^{-}$ & +1.2 \\
Oxygen & $2 \mathrm{H} \leftrightarrow \leftrightarrow \mathrm{O}_{2}+4 \mathrm{H}^{+}+4 \mathrm{e}^{-}$ & +1.23 \\
Chlorine & $2 \mathrm{Cl}^{-} \leftrightarrow \mathrm{Cl}_{2}+2 \mathrm{e}^{-}$ & +1.36 \\
Gold & $\mathrm{Au} \leftrightarrow \mathrm{Au}^{+++}+3 \mathrm{e}^{-}$ & +1.50 \\
\hline
\end{tabular}

Source: Boldt 1967.

Iron is normally removed by aerating the solution to oxidize the ferrous iron and precipitate it as ferric hydroxide. The ferric hydroxide also incorporates other impurities such as lead and arsenic. The precipitate which is filtered from the solution is formed by the reaction:

$$
\mathrm{Fe}^{+++}+3 \mathrm{H}_{2} \mathrm{O} \rightarrow \mathrm{Fe}(\mathrm{OH})_{3}+3 \mathrm{H}^{+}
$$

Cobalt is normally precipitated as a hydroxide by treatment with chlorine, with nickel carbonate added for $\mathrm{pH}$ control:

$$
2 \mathrm{Co}^{++}+\mathrm{Cl}_{2}+3 \mathrm{NiCO}_{3}+3 \mathrm{H}_{2} \mathrm{O} \rightarrow 2 \mathrm{Co}(\mathrm{OH})_{3}+3 \mathrm{Ni}^{++}+2 \mathrm{Cl}+3 \mathrm{CO}_{2}
$$

Two different methods of electrowinning are generally employed. One uses soluble anodes of nickel sulfide, and the other uses insoluble anodes to extract the nickel from a leach solution. In all cases there is a net cell reaction.

In processes that use nickel sulfide anodes, the anodic reaction is:

$$
\mathrm{Ni}_{3} \mathrm{~S}_{2} \rightarrow 3 \mathrm{Ni}^{++}+2 \mathrm{~S}+6 \mathrm{e}^{-}
$$

And the cathodic reaction is:

$$
3 \mathrm{Ni}^{++}+6 \mathrm{e}^{-} \rightarrow 3 \mathrm{Ni}
$$




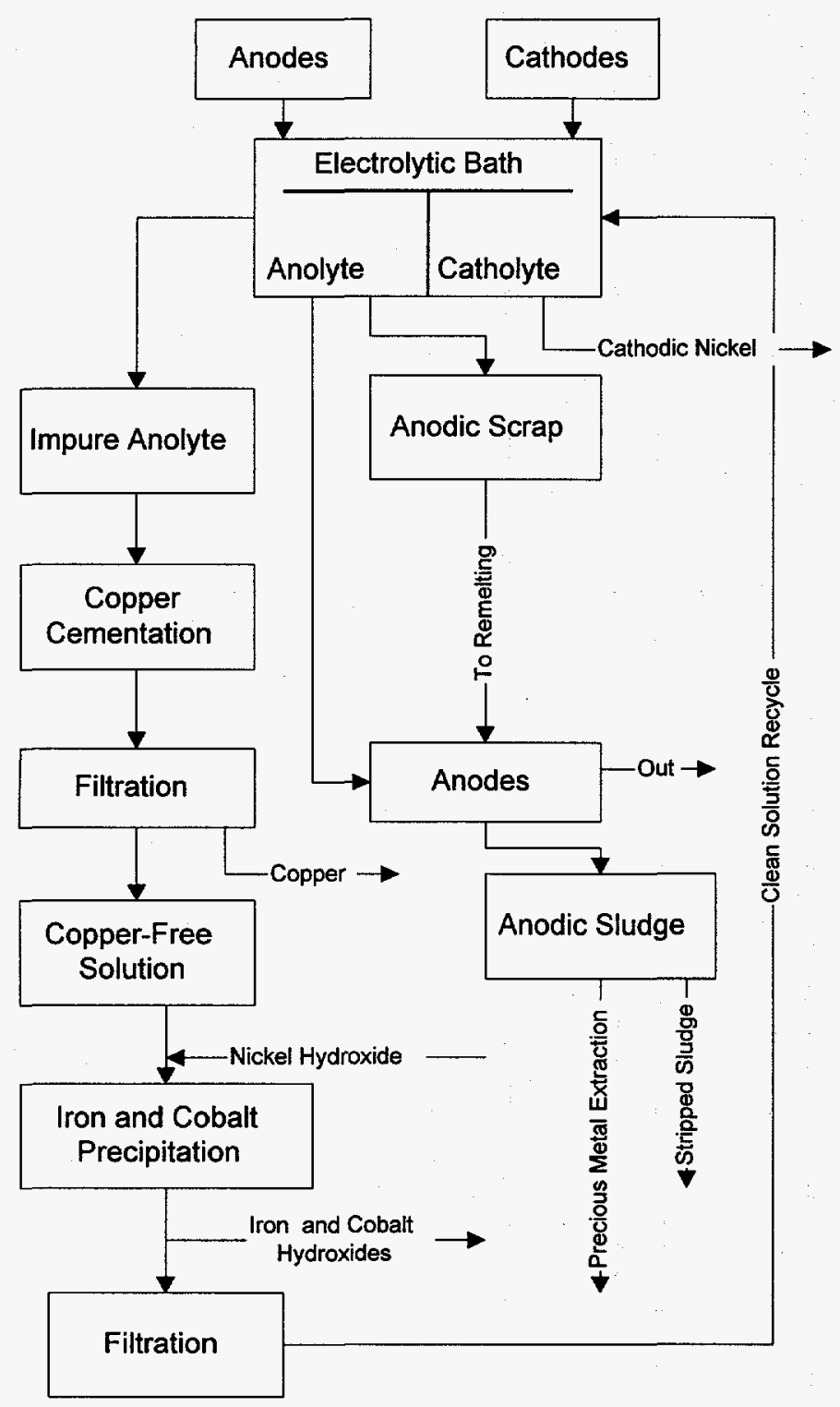

In processes that use insoluble anodes, the nickel in a leach liquid is recovered, and the only function of the anode is to transfer electrons to the external circuit. Thus there is no requirement for casting impure nickel anodes or to collect tank slimes. The leach liquid is generally an aqueous solution of nickel sulfate, sodium sulfate, and boric acid. The principal anodic reaction is:

$$
2 \mathrm{H}_{2} \mathrm{O} \rightarrow \mathrm{O}_{2}+4 \mathrm{H}^{+}+4 \mathrm{e}^{-}
$$

The principal cathodic reaction is:

$$
2 \mathrm{Ni}^{++}+4 \mathrm{e}^{-} \rightarrow 2 \mathrm{Ni}
$$

Nickel streams evince considerable variability in composition. Because many of the contaminants in these streams are profitably recovered as byproducts, a wide range of process configurations have been developed. Cobalt is recovered in both of the processes detailed above. As discussed earlier, separation of cobalt from nickel is of particular concern because of the presence of ${ }^{60} \mathrm{Co}$ in previously irradiated scrap. The process detailed in Fig. 2.3 recovers copper and precious metal concentrate.

Figure 2.4 illustrates conventional industrial separation and recovery of nickel and cobalt.

Fig. 2.3. Nickel electrorefining from matte. Adapted from Kornilov 1963.

\section{New Electrolyte Developments}

In earlier practice (Boldt 1967), nickel electrorefining was typically performed using a sulfate-based electrolyte like that detailed in Table 2.2. This practice evolved because of the sulfur content of nickel ores and nickel concentrates, and because of the limited 


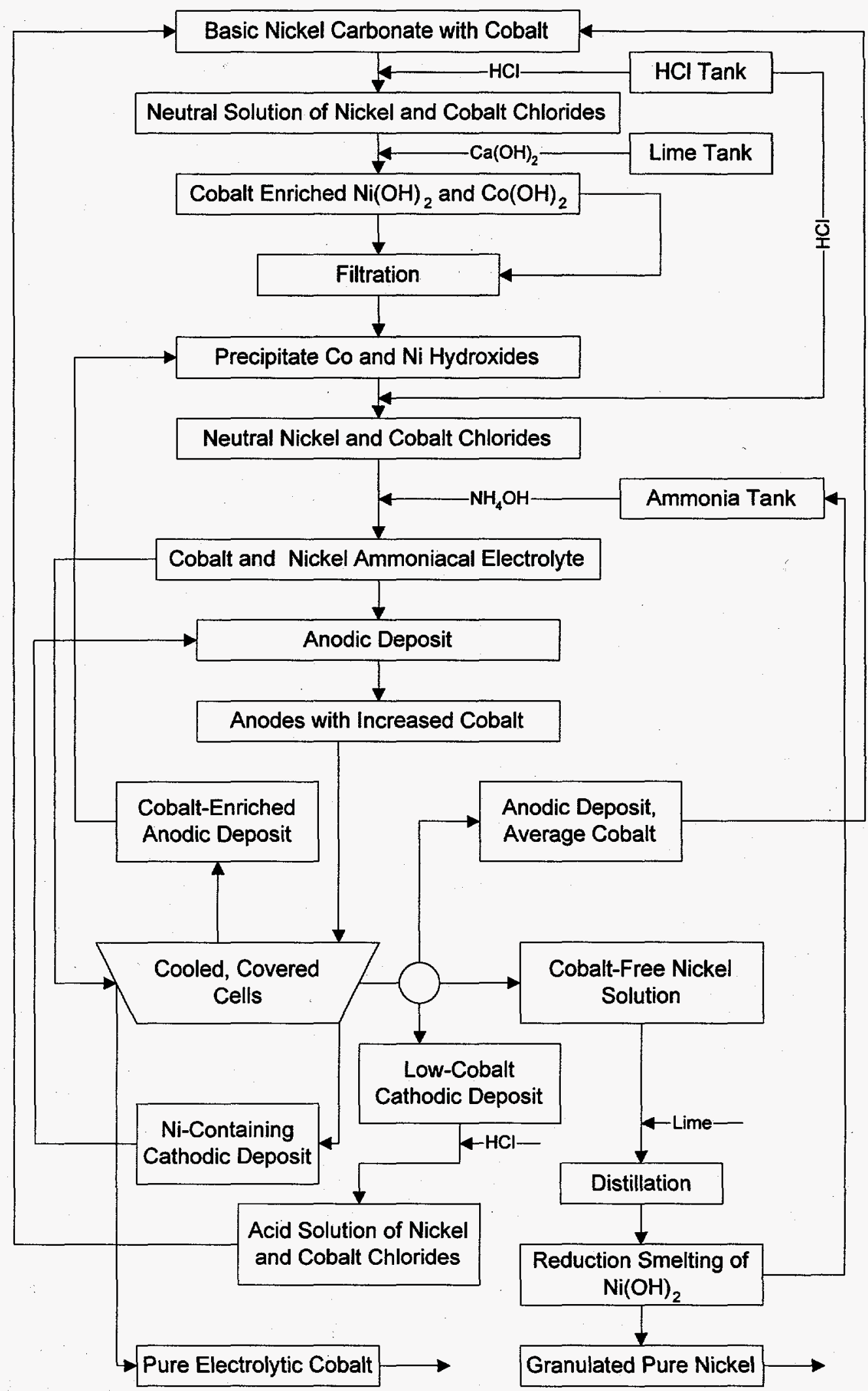

Fig. 2.4. Electrolytic separation of nickel and cobalt. Adapted from Kornilov 1963. 
evolution of gas in tankhouse operations. However, Ettel (1983) indicated that new and increasingly stringent environmental regulations may require collection of gas from sulfate-electrolyte tanks. This is encouraging the adoption of chloride-based leaching

Table 2.2. Electrolyte for conventional nickel electrorefining

\begin{tabular}{lc}
\hline Ion & Concentration, $\boldsymbol{M}$ \\
\hline $\mathrm{Ni}^{+-}$ & 1.022 \\
$\mathrm{SO}_{4}^{-}$ & 0.989 \\
$\mathrm{Na}^{+}$ & 1.522 \\
$\mathrm{Cl}^{-}$ & 1.551 \\
$\mathrm{H}_{3} \mathrm{BO}_{3}$ & 0.258 \\
\hline
\end{tabular}

Adapted from Boldt 1967. solutions and electrolytes for electrowinning. Although individual tanks (and, in some cases, individual anodes) must be outfitted for chlorine gas collection, chloride-based electrolytes have several advantages over sulfate-based systems. These include higher metal solubility, almost-permanent anodes, and potentially lower cell voltages due to low $\mathrm{Cl}_{2}$ overpotential and high conductivity. Discussions with International Nickel Company, Inc., staff indicated that major refiners have begun converting from sulfate-based operations, including matte

leaching, to chloride-based operations (Conard 1994). There has also been French interest in developing chloride-based proceses (Demarthe, Gandon, and Goujet 1983).

The Falconbridge Nikkelverk at Kristiansand, Norway is the first large-scale plant employing an electrowinning process to use a chloride electrolyte (Stensholt and coworkers 1988). As shown in Fig. 2.5, chlorine leaching is used to selectively dissolve nickel from the incoming matte. This leaves a solid sulfide high in copper. The nickel solution is treated to remove iron and arsenic and solvent extracted to remove cobalt. Following a final precipitation to remove lead and other residual impurities, nickel is recovered from the solution by electrowinning. Chlorine gas produced during electrowinning is recycled to matte leaching. Cobalt is back-extracted from the solvent stream and recovered by electrowinning. The nickel produced by the Falconbridge Nikkelverk is very pure.

Radioactive contaminants in DOE nickel scrap include: ${ }^{234} \mathrm{Th},{ }^{234} \mathrm{~Pa},{ }^{137} \mathrm{Cs},{ }^{239} \mathrm{Pu}$ (trace), ${ }^{60} \mathrm{Co}, \mathrm{U},{ }^{99} \mathrm{Tc}$, and ${ }^{237} \mathrm{~Np}$ (trace). As discussed below, chloride-based systems have good potential for simplifying ion exchange and solvent extraction separations of radiological contaminants from nickel. Chloride, as opposed to sulfate, systems may facilitate separations of uranium, the major radiological contaminant, from nickel.

Nitrate systems could also be used for nickel recovery by electrolysis. These systems have historically been used in uranium operations. For that reason, separations of a variety of daughter products and transuranics from nitrate solutions into various organic extractants have been well studied.

\section{Advances in Cell Architecture}

Conventional nickel electrowinning and electrorefining cells usually employ parallel plate geometry. Materials of construction are typically concrete or wood tanks coated internally to minimize damage by the electrolyte (Boldt 1967). Because materials and processes have evolved throughout a plant's history, often for several decades, changes can be both difficult and expensive.

As a startup operation, the nickel scrap electrorefining process should selectively employ modern technology to meet the difficult operating conditions likely to be imposed on the facility. These may include: minimization of leaks; minimization of radioactive contamination; provisions for safe handling of radioisotopes, including any criticality 

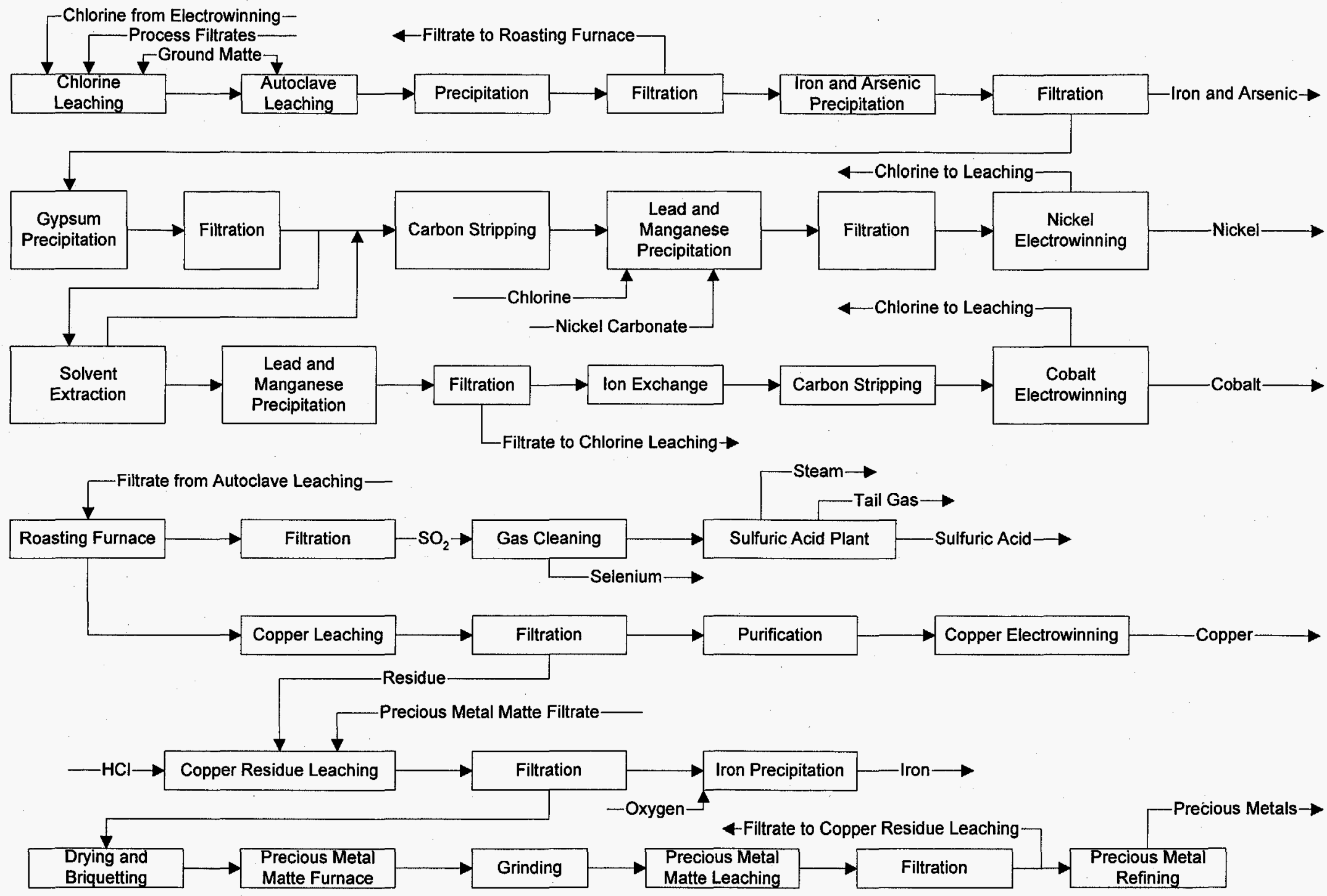

Fig. 2. 5. Falconbridge Nickel Refinery chlorine-based process. Modified from: Stensholt and coworkers 1988. 
control; and ability to vary process configuration, including side-stream processing, to accommodate variable feedstocks; and the ability to adjust operation to meet facility operating time demands. Safety and accountability will also continue to be of primary concern.

Some novel electrochemical cell geometries appear well suited to nickel scrap reprocessing. As discussed by Flett and Evans (1983), cells which produce powdered metal continuously from chloride solutions, such as the Duval CLEAR process for copper, are of particular interest here because they have the potential for eliminating cathode handling. Boldt (1967), in discussions of conventional technology, indicates that a conventional nickel electrorefining plant employing a 31 anode, 30 cathode per tank, parallel plate configuration, will process roughly 90 tons per tank per year. Using reported process data for the Inco Port Colborne facility, anodes will be changed 12 times, cathodes, 36 . Anodes are typically 36 in. $\times 27$ in. $\times 1.75$ in. and weigh $500 \mathrm{lb}$. For every ton processed, eight electrodes will have to be prepared and changed out.

Other innovations include fluidized bed electrodes, such as the Chemelec cell employed by Chaudhary (1990) in nickel electrorefining. These cells use a fluidized bed of inert beads to decrease concentration polarization at the surface of a metal-mesh cathode. Although they are successful in increasing throughput, the mechanical complexity and possibility of increased waste production decrease the potential utility of this technology.

Several novel process geometries have been adapted for precious metal recovery. These include the static cylinder electrode, the rotating cylinder electrode, the rotating tubular electrode, and the impact rod reactor. The low metal and low volume holdups provided by these systems could minimizing process volumes. All of these systems except for the rotating tubular reactor are in commercial usage

Of particular interest is the ability to change cell structure and geometry to adapt to changing feedstocks or requirements. A catalog search indicated that this capability is provided by a number of different commercial units. Typical configurations include stacked plates separated by gasket seals and compressed with corner screws. Although these units are typically smaller than those common to tankhouse operations, cell component changes can be made by inserting or removing units in the process stack. Because these units are similar in construction to a standard plate and frame filter press, there is a reasonable likelihood that manufacturing and maintenance operations can be automated in an analogous fashion. Where process solutions and anodes contain radioisotopes, automation could be a major advantage.

\section{Advances in Separator Materials}

New process developments are likely to use high performance, modern materials of construction to improve Separator performance. In the conventional industrial scale nickel electrowinning or electrorefining described by Boldt (1967), electrolyte high in material freshly dissolved from the anode, or anlolyte, is removed from the cell. Using a variety of conventional chemical processes, impurities are precipitated from the electrolyte. Purified electrolyte is re-introduced to the cell through a canvas bag placed around the cathode. The canvas bag placed around the cathode restricts flow, permitting the development of a small differential pressure. By causing liquid to flow away from the cathode, this technique improves the purity of the electrolyte around the cathode and, hence, of the cathode itself. Modern materials may be more durable and may selectively retard contaminant passage. 
As reported by Yeo (1983) a number of types of advanced materials are now being used to construct separators for electrochemical cells. These materials are typically more expensive than is canvas. However, they can often provide a secondary separation or enhance an existing separation. Materials which might be of particular use in nickel electrorefining cells include woven glass cloths; polyvinyl chloride cloths; fluorocarbon cloths; porous aluminum oxide ceramics; particulate ion exchange resins, including Nafion and related ionomers; and reinforced ion exchange resin sheet. Most of these materials are commercially available.

Several considerations dominate the choice of separator for a nickel electrorefining system. The first question is the choice of cell electrolyte. If a relatively simple electrolyte, such as chloride, is chosen, it may be possible to make effective use of an ion exchange membrane to improve separation. Temperature is a major consideration in separator selection. If it is appropriate to operate cells at high temperatures, then membranes capable of providing long service in warm or hot operating conditions will be favored. Thermal stability in an acid, high-chloride environment encourages the use of polyvinyl chloride, fluorinated and perfluorinated materials (teflon), Nafion, and other similar materials.

One particularly interesting idea is the creation of membranes tailored to specifically and selectively remove trace quantities of radioisotopes in the scrap. The work of Kang, Kim, and Kim (1990), which describes polymeric membranes through which uranium may be preferentially extracted, is an early example of selective membrane separators.

\section{Contaminant Separation Processes}

Nickel recovered from gaseous diffusion plants scrap may contain radioisotopes in addition to alloying materials and impurities. Removal of radioisotopes has high priority from environmental, safety, and health standpoints. With the exception of uranium, which may reach ppt levels, radiological contaminants are expected to fall in the ppb to ppm range. Ion exchange, solvent extraction, and surface sorption are all processes which effectively remove trace contaminants. If highly successful contaminant removal is effected, it may be possible to recycle the nickel scrap for use within the DOE system. If DOE and the NRC are able to reach consensus on de minimus levels of radioisotopes, and if radiological contaminant removal processes are very efficient, it may be possible to recycle nickel for industrial use. Both electrolyte and contaminant removal systems must be carefully tailored to each other and to the process to meet these goals. The techniques discussed below may be useful in final recovery or disposal of contaminants, as well as in removing them from process electrolyte streams.

Precipitation and cementation. Precipitation and cementation, as discussed above, have historically been used to remove contaminants from industrial nickel processing streams because they are inexpensive and because they typically permit byproduct recovery. Copper, iron, and other high-volume impurities are precipitated from conventional nickel refining streams as sulfides or oxides. Cementation is used to remove low volume impurities. Electrochemical values indicate that this technique may be used to remove technetium from nickel streams.

Precipitation may be a particularly attractive option for technetium removal. Meyer and coworkers (1989) indicated the possibility of precipitating technetium from basic solutions. Average value of solubilities for hydrous oxides of $\mathrm{TcO}_{2} \cdot \mathrm{nH}_{2} \mathrm{O}$ was estimated to be $3 \times 10^{-9}$ $\mathrm{mol} / \mathrm{L}$ at $\mathrm{pH}$ values between 6.9 and 9.3 in $0.05-2.6 \mathrm{M} \mathrm{NaCl}$ solutions. The oxides had an 
average hydration of 1.6. Oxides deposited in acid conditions were found to be more soluble than those deposited in basic solutions. Solubility of the oxides was highest in acid solutions, lowest near neutrality, and rose slightly in alkaline solutions (Meyer and coworkers 1991). The standard potential for the $\mathrm{Tc}(\mathrm{VII})-\mathrm{Tc}(\mathrm{IV})$ redox couple was also redetermined (Meyer and Arnold 1991) and found to be $0.747 \pm 0.004 \mathrm{~V}$. This agreed with earlier reports by Cartledge (1971).

Peacock, in a comprehensive review of technetium chemistry, indicates that it may be possible to precipitate Tc from acid solution as a sulfide (1973). Technetium can also be extracted from alkaline solutions by pyridine and, as pertechnetate, from acid solutions by alcohols, esters, ketones, ethers, amines, and hydrocarbons. Hexachlorotechnetate (IV) ion is readily extracted from $6 \mathrm{M} \mathrm{HCl}$ into trioctylphosphine oxide in cyclohexane. The ability of technetium to form complexes may play a significant role in development of solvent extraction systems.

Process evaluations should include both cementation and precipitation because they may provide inexpensive, low volume removal of the bulk of a given contaminant. It is likely that these techniques will need to be followed by solvent extraction or ion exchange to meet radioisotope standards because radiological contaminants may be at levels low enough to limit the fraction which can be precipitated.

Ion exchange. Ion exchange has historically been effective in removing low and trace level contaminants from salt streams. The contaminants can be recovered as small volumes of concentrates. In some cases, it is also possible to use ion exchange to remove several low or trace contaminants on one exchanger at one time.

The applicability of ion exchange depends on the composition of the nickel electrolyte. Consider the feed of Table 2.2, which has as major components about $1 M \mathrm{NiSO}_{4}$ and $1.5 M$ $\mathrm{NaCl}$ with $\mathrm{pH}$ buffered to be from weakly acidic to weakly neutral. Information bearing on solutions with anions that might result from alternative schemes is also discussed. For the composition of Table 2.2, the literature indicates, but does not establish, that strong-base anion exchangers may be useful. Purifications based on anions are also attractive, particularly if chloride is present in substantial concentration. Although $\mathrm{Ni}$ (II) does not form chloride complexes to a significant extent, many of the substances to be removed do. It may be feasible therefore to remove the contaminants from a substantial volume by passage through a column. and to regenerate the column by eluting with small volumes of a solution or solutions for which the distribution coefficients of the contaminants are small. (The number of column volumes that can be treated in a cycle is approximated by the value of the distribution coefficient.) Because the behavior of liquid extractants frequently parallels that of chemically similar solid ion exchangers, the same argument can be made for these systems.

Diamond and Whitney (1966) present, for wide ranges of concentration of several electrolytes, summaries of distribution coefficients of most metallic ions in the periodic table. The most pertinent for the composition here are in Fig. 6, from Kraus and Nelson (1956), dealing with adsorption from 0.1 to $12 \mathrm{M} \mathrm{HCl}$ on Dowex-1, a quaternary-amine exchanger. At about $2 M \mathrm{HCl}, \mathrm{Ni}(\mathrm{II})$ is not adsorbed, whereas the distribution coeffient of technetium is over 100. (Although shown as Tc(VII), there is some question about the valence state of Tc in high concentrations of hydrochloric acid.) $\mathrm{Co}$ (II) is not adsorbed appreciably at $\mathrm{HCl}$ concentrations below $5 \mathrm{M}$, and the distribution coefficient of U(VI) and other actinides does not reach 100 until $4 M$. However, in $\mathrm{LiCl}$ (plus $0.1 M \mathrm{HCl}$ ), 
distribution coefficients were found to be a hundred times greater for many species, including $\mathrm{Co}(\mathrm{II})$ (Kraus, et al, 1955). Similar selectivities were also found for $\mathrm{CaCl}_{2}, \mathrm{MgCl}_{2}$, and $\mathrm{AlCl}_{3}$ (Kraus and Nelson (1958)). If such enhancements of selectivity occur with nickel chloride as supporting electrolyte, and sulfate does not interfere, most of the contaminants could be removed by passage through an ion-exchange bed. ( $\mathrm{Cs}^{+}$exclusion from the nickel product would presumably occur in the plating.) Bench-scale tests would be necessary to establish feasibility at finite loadings of adsorbates in solutions of interest and to identify suitable eluting solutions, but these tests should require little effort.

The Diamond-Whitney review cited above also contains a periodic-table representation of adsorption from nitric acid solutions from a publication of Faris and Buchanan (1964). $\mathrm{Ni}$ (II) is not adsorbed, and Tc(VII) is. In this medium, technetium is probably present as the pertechnetate ion. However, Co(II) is not adsorbed from the acid. Unless there is an enhancement of selectivity with supporting electrolytes of metallic cations paralleling that observed in chloride media, cobalt removal from the feed would not occur. Such an enhancement of selectivity for U(VI) in nitrate salt solutions does occur (Kraus and Nelson (1958)).

Measurements of the distributions of a large fraction of the periodic table are available for other media and exchangers: for $\mathrm{HCl}-\mathrm{HF}$ on an anion exchanger (Kraus, et al (1962)); for $\mathrm{HBr}$ on a strong-acid cation exchanger (Nelson and Michelson (1966); from $\mathrm{HCl}$ and from $\mathrm{HClO}_{4}$ on a cation exchanger (Nelson, et al (1964); and from $\mathrm{HClO}_{4}-\mathrm{Cl}$ mixtures on a cation exchanger (Nelson and Kraus(1979)). The media are different from those projected here, and the selectivities do not appear promising for this application, but the information may be useful in selection of eluting media. We are not aware of systematic studies of sulfate media, perhaps because fewer elements seem to be adsorbed from these solutions. However, U(VI) is absorbed and industrial processes for recovery of it from leach liquors of low-grade ores have been based on this behavior (Kraus and Nelson (1958)).

Palmer and Meyer (1981) report distribution coefficients for pertechnetate from $0.1 \mathrm{M}$ $\mathrm{NaCl}$ of 20,000 on Dowex $1 \times 10$, and values in the same range on a weak-base anionexchanger, Amberlite IR-45 at $\mathrm{pH}$ below 7; at higher $\mathrm{pH}$, values drop off for IR-45.

Hurst (1976) discusses cobalt-nickel separations in ammonium-ammonium carbonate solutions on Dowex $50 \times 8$, a strong-acid conventional cation exchanger with which when adsorption is not heavily influenced by formation of complexes with anions)

On the inorganic ion-exchanger, $\mathrm{Al}_{2} \mathrm{O}_{3}$, Palmer and Meyer (1981) found that selectivities for $\mathrm{Tc}$ (VII) were relatively low, and decrease with increase of both $\mathrm{pH}$ and supporting electrolyte concentration; for example, the distribution coefficient, $\mathrm{D}$, from $0.01 \mathrm{M} \mathrm{NaCl}$ at $\mathrm{pH} 4$ is about $30 \mathrm{~L} / \mathrm{kg}$ and about 10 from $0.1 \mathrm{M} \mathrm{NaCl}$. However, D of several hundred was observed on $\mathrm{ZrO}_{2}$ from $0.01 M \mathrm{NaCl}$ at low $\mathrm{pH}$. Shiao, et al, (1981) reported $\mathrm{D}$ values of greater than 105 for $\mathrm{Co}(\mathrm{II})$ on $\mathrm{Al}_{2} \mathrm{O}_{3}$ at $\mathrm{pH} 8$ and above, not very sensitive to $\mathrm{NaCl}$ concentration, with a rapid decline in acidic media. Maeck, et al, (1963) found relatively small differences in selectivities for nickel, cobalt and technetium on hydrous $\mathrm{Zr}$ (IV) oxide and the mixed hydrous oxide exchangers $\mathrm{Zr}$ (IV)-P(V), Zr(IV)-Mo(VI), and Zr(IV)-W(VI) (Kraus, et al (1958)) from $0.005 M$ nitrate solutions, pH 1 to 5 .

Activated carbon removed Tc from a simulated ground water with distribution coefficients of several hundred; the pertechnetate was believed to have been reduced in the adsorption (Johnson, et al (1984)). Co(II) is also strongly adsorbed on activated carbon (Johnson, et 
$a l,(1986))$, and the distribution coefficients are greatly increased, if the carbon has been pre-oxidized with nitric acid (for example, $D$ increases from about 400 to over 10,000 from $0.2 \mathrm{M} \mathrm{NaCl}, \mathrm{pH} 5$ ). It is likely however that $\mathrm{Ni}(\mathrm{II})$ would also be adsorbed under these conditions, so the practical implications may be limited.

Ion exchange has also been used, as reported by Williams and cohorts (1993) in the separation of contaminated nickel HFIR targets.

Solvent extraction. Solvent extraction is widely used to in the nuclear reprocessing industry. This process is readily adapted to safe-geometry requirements and, with appropriate process design, can provide exceptionally high contaminant removal efficiencies. It may also be possible to define conditions within which several contaminants are removed in a single process. Several of the extractants discussed below have this potential.

Cobalt is readily removed from nickel streams by extraction of a cobalt complex. Griffith, Jasney, and Tupper investigated the removal of cobalt from nickel in a chloridethiocyanate system using methyl isobutyl ketone as an extractant (1952). This study explored operating parameters for a countercurrent pulse column system. Although the distribution coefficients were relatively low, typically 0.2 to 3 , good separations were effected because the equilibrium distance, or height of a theoretical unit, was, for selected operating conditions, on the order of an inch. A major drawback is the high amount of thiocyante, relative to cobalt concentration, required to drive formation of cobalt tetrathiocyanate complexes. A corresponding process advantage is the near-total exclusion of nickel from the organic phase.

This system is known to work under achievable, pilot-scale operating conditions using extractants proven by extended in-house experience. Several modern technologies, such as static mixers, improved pump materials, and improved phase separations, are likely to enhance performance. Systematic studies to optimize phase composition could also play a major role in improving performance. However, assuming equal organic and aqueous concentrations, and assuming ten theoretical units per foot, we calculate that the system will decrease cobalt concentration by three orders of magnitude per foot of column.

Cobalt thiocyanate complexes are readily analyzed spectrophotometrically, and, as in the work discussed above, can be separated readily by solvent extraction. The cobalt thiocyanate complex system forms the basis for a number of analytical techniques. Several of these techniques employ complexing agents which may be used to enhance process cobalt separations.A variety of inorganic separations methods could potentially remove cobalt from nickel solutions. Lazic and Vukovic reported the separation of ${ }^{137} \mathrm{Cs}$ and ${ }^{60} \mathrm{Co}$ from an acidic nuclear wastewater into potassium cobalt hexacyanoferrate in alkaline ( $\mathrm{pH}$ 8.5-11.3) solution (1991). Flocculation of the precipitate with a variety of polyelectrolytes was evaluated. Most efficient removal of both radionuclides was obtained at $\mathrm{pH} 10$ with a $\mathrm{Co}: \mathrm{Fe}(\mathrm{CN})_{6}$ of 2 . Filtration properties of the precipitate were substantially improved by flocculation with cationic acrylamid polyelectrolytes (Praestol 511K, 522K, and 533K).

The many valences and complicated complexes formed by technetium make understanding its chemistry difficult. Spitsyn and coworkers (1964) evaluated extractants for ${ }^{99} \mathrm{Tc}$ from concentrated acidic solutions characteristic of nuclear processing. As shown in Table 2.3, ${ }^{99} \mathrm{Tc}$ is readily extracted by acetone, quinoline, or tributyl phosphate. Based on these 
results, it is likely that a nearly quantitative process for technetium removal from acidic nitrate solutions can be developed.

Bonnesen and coworkers report considerable success in removing pertechnetate ion from high concentration nitrate solutions characteristic of DOE metal process wastes. These researchers developed and evaluated solvent extraction systems which included ketones or pyridines, and aliphatic hydrocarbon, and crown ethers. These systems preferentially removed sodium from ${ }^{99} \mathrm{Tc}$-spiked simulated process streams. Associated pertechnate ions come with the sodium to maintain charge balance. In addition to providing excellent ${ }^{99} \mathrm{Tc}$ removal, these systems have high flash points, low toxicities, and can be stripped of pertechnate with distilled water.

Table 2.3. Technetium extraction from industrial nitrate solutions

\begin{tabular}{lccc}
\hline Extractant & Conditions & Distribution coefficient & Fraction Tc in organic phase $^{\mathrm{a}}$ \\
\hline Acetone & $3 \mathrm{~N} \mathrm{NaOH}$ & 10,000 & 0.98 \\
Quinoline & $\mathrm{pH} \mathrm{11.8}$ & 1,000 & 0.58 \\
Tributylphosphate & $0.5 \mathrm{~N} \mathrm{HNO}_{3}$ & 100 & 0.56 \\
Isoamyl alcohol & & 10 & 0.60 \\
\hline
\end{tabular}

Adapted from:: Spitzsyn and coworkers 1964.

Other extraction processes, such as Japanese schemes for partitioning Tc into activated carbon and eluting it with thiocyanate, may also be useful (Fujito and coworkers 1993, Yamagishi and Masumitsu 1988, 1990, 1993). As indicated by Konno and Hidaka (1989) Tc also forms complexes with a variety of other ligands, including halides. Other extractants reported effective include: 5-(4-pyridyl)nonane (Ejaz and Mamoon 1988); polyurethane foam with a cyclic polyether (Caletka, Hausbeck, and Krivan 1986); tri-nocylamine (Gorski, Gruendig, and Richter 1984; Gorski, Richter and Hennrich 1982); 2hexylpyridine (Hanif, Hasany, and Ejaz 1977); tricaprylmethylammonium nitrate (Horowitz and Delphin 1979); and a novel biphasic polyethylene glycol system (Chaiko, Vojta, and Takeuchi 1993).

The high distribution coefficients for ${ }^{99} \mathrm{Tc}$ extraction indicate the possibility of removing this material from nickel electrolyte solutions. However, technetium is best extracted from concentrated, highly acidic solutions. The electrolyte solutions typically used in nickel electrorefining are usually weakly acidic. It is likely that a chloride, rather than nitrate or sulfate, electrolyte will be used because it improves cell operation and also facilitates any ion exchange separations. In order to determine the best process for separating technetium, it will be necessary to evaluate distribution coefficients in proposed process solutions.

Solvent extraction has been used extensively to purify uranium for recycle within the DOE system. Research indicates that many classes of materials, most notably crown ethers, polyethers (Googin and coworkers 1962), organonitrates (Diamond and coworkers 1979), organophosphines, organophosphates (Jankowska, Kulawik, and Mikulski 1980;

Grychowski and coworkers 1981), and solid-phase cryptands, readily extract uranium from aqueous solutions. The number of studies on the stability, cost, and physical properties of carbitol and tributyl phosphate systems (Pushlenkov and Zimenkov 1979; Rochon and Nowak 1979; Barreta 1980; Fabre 1980; Mailen 1981; Frietas 1982; Orth, Martin, and 
Pickett 1983; Hyder and coworkers 1979) provides a measure of their utility in industrialscale uranium purification. Although a variety of aqueous systems have been used, most studies involve nitrates. Petrich and Kolarik (1981), for example, correlated published data on distribution of $\mathrm{U}, \mathrm{Pu}$, and $\mathrm{Np}$ between aqueous nitrate solutions and tributyl phosphate in alkanes. Their survey found more than 4200 sets of distribution data for these systems.

From the data for Tc in Table 2.3, it appears that it may be possible to define conditions under which both uranium and Tc can be concurrently removed from the nickel electrolyte stream by a single extractant, such as tributyl phosphate.

Success with variety of other uranium extractants has been recently reported. Solidsupported exchange into liquid extractants has also been demonstrated by the work of Kang, Kim, and Kim (1990). These investigators used a microporous polymer to support a solvent containing alamine 336, tri-n-octyl phosphine oxide, tri-n-butyl phosphate, and di(2-ethylhexyl) phosphoric acid. This "membrane" permits the exchange of uranium between two aqueous phases. This technology, together with a gel-phase extractant reported by the same investigators, could serve as the basis for development of new extraction processes. It could also be used as the basis for development of separator membranes for electrolytic cells. Similarly, polyurethane foam, either alone or with hexanone, has been used to extract uranium from nitric acid in the presence of a variety of salting agents (Korkisch, Steffan, and Navratil 1981).

Grychkowski and coworkers (1981) and Jankowsak, Kulawik, and Mikulski (1980) reported the use of octaethyltetraamidepyrophosephate (OETAPP) as a uranium extractant. Use of OETAPP in a $\mathrm{CCl}_{4}$ solution to extract uranyl nitrate yields a precipitate tentatively identified as OETAPP $\mathrm{UO}_{2}\left(\mathrm{NO}_{3}\right)_{2}$. OETAPP is an effective extractant for uranium, thorium, hafnium, and iron from chloride solutions.

Nickel scrap from DOE operations may also contain a variety of radioisotopes at very low or trace concentrations. These could include: ${ }^{234} \mathrm{Th},{ }^{234} \mathrm{~Pa},{ }^{137} \mathrm{Cs},{ }^{239} \mathrm{Pu}$, and ${ }^{237} \mathrm{~Np}$, as well as the higher levels of ${ }^{60} \mathrm{Co}, \mathrm{U}$, and ${ }^{99} \mathrm{Tc}$ discussed above. One particularly interesting idea is the creation of "disposable" membranes tailored to specifically and selectively remove trace quantities of radioisotopes present in the scrap to be treated. Such a membrane would be expected to consist of a support phase to which was attached groups highly selective for removal of a given radioisotope. Two new Japanese process, a uranium enrichment technique and a new Japanese technique for selectively removing uranium from seawater, use this type of technology to good effect.

Some solvent extraction procedures have also been developed for these materials.

Protactinium has been reported to be readily extracted from sulfate-chloride medium into amyl acetate (Walker and Short 1979). It can be backwashed into a chloride-fluoride medium. Other methods for purification of trace transuranics from fuel reprocessing streams have included denitration and calcining (Rimshaw and Case 1980), extraction with low concentrations of TBP (Orth, Martin, and Pickett 1983), and addition of hydroylammonium nitrate and hydrazine, followed by extraction with dihexoxyethyl phosphoric acid in an organic diluent (Horwitz, Delphin, and Mason 1979). 


\section{Advanced Integrated Process Development}

The widespread use of nickel within the nuclear industry has encouraged bench and pilot scale development of the variety of recovery processes summarized in Table 2.4. These processes typically have several common features. The technologies combine features of industrial electrowinning and electrorefiing processes with those of the electrostripping and solvent extraction processes used historically in the nuclear industry. Most of the patents cover single unit processes which are part of a larger metal recovery scheme. Westinghouse, in a variety of research and development projects spanning more than a decade, has maintained an active interest in this area.

Table 2.4. Advanced nickel decontamination processes

\begin{tabular}{|c|c|c|c|c|}
\hline Process & Patent or SIR & Assignee & Date & Inventor(s) \\
\hline Electrolytic decontamination & U. S. $4,318,786$ & Westinghouse & 1982 & $\begin{array}{l}\text { E. J. Lahoda } \\
\text { D. A. Eckhardt } \\
\text { D. L. Grover }\end{array}$ \\
\hline $\begin{array}{l}\text { Method for decontamination of nickel-fluoride- } \\
\text { coated nickel containing actinide-metal fluorides }\end{array}$ & U. S. $4,421,556$ & U.S.D.O.E. & 1983 & $\begin{array}{l}\text { N. F. Windt } \\
\text { J. L. Williams }\end{array}$ \\
\hline Decontamination using electrolysis & U.S. $4.537,666$ & Westinghouse & 1985 & $\begin{array}{l}\text { A. P. Murray } \\
\text { T. S. Snyder }\end{array}$ \\
\hline $\begin{array}{l}\text { Electrolytic decontamination process and process } \\
\text { for reproducing decontaminating electrolyte by } \\
\text { electrodeposition and apparatuses therefore }\end{array}$ & U.S. $4,615,776$ & $\begin{array}{l}\text { Shinko- } \\
\text { Pfaudler }\end{array}$ & 1986 & $\begin{array}{l}\text { T. Sasaki } \\
\text { T. Kobayaski } \\
\text { K. Wada }\end{array}$ \\
\hline $\begin{array}{l}\text { Electrolytic decontamination apparatus and } \\
\text { encapsulation process }\end{array}$ & U.S. $4,792,386$ & Westinghouse & 1988 & $\begin{array}{l}\text { T. S. Snyder } \\
\text { A. P. Murray }\end{array}$ \\
\hline $\begin{array}{l}\text { Process for decontaminating radioactivity } \\
\text { contaminated metallic materials }\end{array}$ & U. S. $4,828,759$ & & 1989 & J. Hanulik \\
\hline Integrated decontamination process for metals & U.S. H970 & U. S. D. O. E. & 1991 & $\begin{array}{l}\text { T. S. Snyder } \\
\text { A. P. Murray }\end{array}$ \\
\hline Decontamination of radioactive metals & U.S. $5,156,722$ & Westinghouse & 1992 & $\begin{array}{l}\text { T. S. Snyder } \\
\text { W. R. Gass } \\
\text { S. A. Worcester } \\
\text { L. J. Ayers }\end{array}$ \\
\hline $\begin{array}{l}\text { Method of indirect chemical reduction of metals in } \\
\text { waste }\end{array}$ & U. S. $5,358,549$ & $\begin{array}{l}\text { Molten Metal } \\
\text { Technology }\end{array}$ & 1994 & $\begin{array}{l}\text { C. J. Nagel } \\
\text { R. D. Bach }\end{array}$ \\
\hline
\end{tabular}

Although comparatively new research indicates international interest in contaminated nickel recovery, it is important to recognize the differences in operation and scale between pilot processes and industrial installations. Environmental, safety, and health considerations are increasingly dominating the development of large scale industrial processes. Additionally, a variety of scale-up and process interaction issues, including contaminant buildup and safe geometry, must be assessed during integrated process development. These are discussed in the following chapter. 


\section{Process Development Considerations}

Several different types of processes, electrowinning, electrorefining, vapometallurgy, and high pressure leaching, are used to purify nickel at industrial scale. These processes have reliably produced nickel from a wide variety of feedstocks for decades. Electrochemical processes are used in the majority of industrial plants. The discussion that follows is primarily concerned with meeting the special operating requirements peculiar to the recovery of DOE radiologically contaminated nickel scrap. In consideration of process technology, there are several areas which must be addressed.

The first consideration in evaluating a proposed new technology is the size of the facility required. DOE radiologically contaminated nickel scrap is roughly 200,000 tons of nickel. As discussed earlier, this is roughly equivalent to 3 decades of domestic production. At an annual recovery of perhaps 20,000 tons, DOE nickel scrap processing operations would require a fairly small plant. Extimates of plant size discussed below are based on literature descriptions of conventional industrial facilities.

Electrorefining, the most common nickel recovery process, can be estimated based on the Inco Port Colborne, Ontario facility described by Boldt (1967), which produces 120,000 tons per year to electrorefine nickel from a mixed sulfate - chloride - borate electrolyte. This process technology would require around 2 acres of working space to house 265 tanks each containing 61 electrodes 36 in. $\times 27$ in. with a 4 in. electrode separation. Every year, plant operations would require nearly one-third of a million electrode change-outs. The cells would consume about $2 \mathrm{MW}$ of electrical power on a continuous basis. Nickel refinery operations could typically include electrolyte preparation and cleanup, melting and casting operations, and process controls. Relative to sulfate-based electrorefining, chloride-based electrowinning requires less space (Stensholdt 1988).

Other processes have similar space requirements. The Fort Saskatchewan ammonia leach plant has been discussed in considerable detail by Nashner (1955). The higher purity of DOE nickel scrap (95+\% vs. $12 \%$ ) and the absence of a need for ammonium sulfate coproduction are likely to decrease the overall size of the facility relative to Fort Saskatchewan. However, estimating size based on recovered nickel indicates that a plant recovering 20,000 tons of nickel annually would occupy two to four acres.

As reported by Bale and Chapman, the International Nickel Company's Copper Cliff plant, which recovers nickel using the carbonyl process, is similar in both size and power requirements to conventional electrorefining (1986). However, because of the low inhalation threshold limits for nickel carbonyl, it is likely that the processing area would be surrounded by a barrier space.

Space and power requirements for electrowinning, electrorefining, carbonyl processing, and ammonia leach processing are well within the capabilities of the Oak Ridge Reservation.

\section{Chemical Systems}

Radiologically contaminated nickel scrap is much higher in purity than the concentrates used as feedstock for conventional nickel refining or winning. However, product purity requirements are expected to be substantially higher. It is expected that any full-scale 
process will contain unit operations in which the nickel is dissolved and processed to remove contaminants from the system. Management of the steps involved in dissolution and separation of radiological contaminants are critical to the development of a successful process. The focus in the discussions below is on nickel electrolysis technologies because they represent the bulk of commercial production.

Electrolytes. Ion exchange and solvent extraction systems are likely to be the preferred methods for removing radiological contaminants. It is simpler and easier to develop such separations processes for systems which employ a single electrolyte. At present, nickel electrowinning and electrorefining process technology is moving toward use of a chloride electrolyte because they provide higher throughput, andhigher solution nickel concentrations. At the Falconbridge refinery, a chloride electrowinning system has also increased product purity, minimized the hand-labor associated with anode preparation, and decreased environmental discharges (Stensholt and coworkers 1988).

Use of a chloride electrolyte or a chlorine dissolving system would provide the ability to readily use ion exchange resins for removal of trace contaminants; the ability to readily solvent extract $\mathrm{Co}, \mathrm{U}$, and Tc from nickel; and the ability to directly recycle chlorine gas to dissolve nickel scrap. Chloride systems also offer the ability to directly dissolve and pretreat nickel to remove impurities. Sulfate-based nickel electrorefining systems generally employ an anode which is electrolytically dissolved during processing. Chloride electrolyte systems use a relatively long-lived anode which does not dissolve during processing. This would eliminate most of the labor-intensive steps associated with dissolving anode management: melting, casting, installation, and replacement. In the case of scrap contaminated with relatively volatile radionuclides, such as ${ }^{99} \mathrm{Tc}$, direct dissolution and preprocess decontamination of nickel scrap will also substantially decrease the potentials for both accidental releases and worker exposures. It will also permit better management of unforeseen problems, such as pretreatment failure or unexpected composition variations. With proper design, this type of system could also improve the ability to manage incoming streams with variable constituents: the cell facility and its operations would operate under fairly constant conditions, while the preprocessing would remove radiological contaminants. A chloride electrolyte system could also be useful in sidestream purification for leaching.

In order to evaluate these systems, some gaps in knowledge and experience will need to be filled. Although nickel refiners are beginning to use chloride-based systems, the process experience base with these systems is still limited. Discussions with operating personnel and consultants to provide a better understanding of operating problems will be held. Although the electrochemistry of chloride salts is a generally well known area, there are some knowledge gaps for the proposed systems. The most limited areas appear to be interactions of the mixed metals from this type of nickel scrap in electrochemical cells and the behavior of complexing agents, such as thiocyanate, in the proposed cell systems.

Extractant systems. The DOE has used solvent extraction systems extensively in processing efforts where high efficiency removal of trace contaminants is necessary. Solvent extraction processes are also employed to remove cobalt as a part of routine chemical purification at the Falconbridge refinery.

One of the primary benefits of a chloride electrolyte system would be preprocess dissolution and preprocess treatment of the nickel stream. This would permit removal of the contaminants using solvent extraction or ion exchange. In considering the volumes of 
liquid to be treated, it would be preferable to use solvent extraction to remove the higher volume contaminants, such as $\mathrm{U}$, Tc, and, possibly Co. It may be possible to find solvent extraction conditions which permit the extraction of two or more of these at the same time. The solvent extractants, tri-isooctyl amine and tributyl phosphate, employed in conventional nickel refining, have been used effectively in uranium purification and recovery from nitrate-based systems. From nitrate solutions, TBP is also an effective extractant for technetium. However, there is little reported research on using either amine or phosphate extractants with chloride systems.

For trace contaminants, such as $\mathrm{Np}$ and $\mathrm{Pu}$, the most effective strategy may be removal using a highly specific solid medium, such as an ion exchange resin or a solid-supported cryptand or crown ether. Some of these systems are currently available for use as electrolytic cell membranes.

Although the work that has been performed on solvent extraction of $\mathrm{Co}, \mathrm{Tc}$, and $\mathrm{U}$ from chloride solutions is encouraging, it is limited because most nuclear processing uses nitrate-based systems. Bench evaluations of process parameters, including distribution coefficients, under a range of process conditions are needed. This is expected to involve use of both conventional extractants and several different types of ion exchange and solid complexing agents.

A major concern in the development of solvent extractants is the small amount, typically less than $1 \%$, of solvent in the aqueous phase. Complexing agents may similarly be retained in the aqueous. These materials could interfere with nickel refining in several ways. First, they could carry small, but significant, amounts of radionuclides into an electrolysis cell. In the conditions found in process cells, these materials could facilitate transfer of radionuclides into the cathode by forming mobile, charged complexes. In vapometallurgical processing or leaching, organics may react with process chemicals with undesired effects. Organic breakdown products could also interfere with processing by forming insoluble products, such as oxalates, which must be removed from surfaces and by changing the chemical or electrochemical behavior of the materials being separated. Additionally, decomposition of organics entrained in acid nitrate electrolyte systems could pose a hazard in acid recovery systems. Both the amounts and the types of breakdown products will have to be considered for the systems evaluated.

High efficiency liquid-liquid separations using membrane systems, phase separators, or centrifugal separators, could provide a viable approach to this problem. Other possible solutions include fixed sorbants, such as metal oxide ion exchangers, or solid supported solvents, such as cryptands or biphasic microporous systems. Sorbant systems like activated carbon could also be used for final polishing.

Simulation of chemical system and process parameters. A nickel refining process capable of treating radiologically contaminated nickel scrap will be a complicated, highly integrated system. It is expected to include gas recycle and scrap dissolving, impurity removal, electrolytic nickel recovery, and waste handling. Optimization of the system as a whole may require operation in regimes not optimal for a single processing step.

Additionally, materials flow from one step to another. Computer simulations will be used to develop an optimal system which minimizes waste production and maximizes nickel production at acceptable cost and safety. In addition to providing estimates of the process areas where changes are the most needed or will be the most effective, simulation studies will help to build a technology base for the process design studies that follow. 


\section{Health and Safety}

In the DOE system, health ans safety have a very high priority. In addition to the health and safety considerations of the conventional nickel electrorefining industry, contaminated nickel scrap recycle presents some special difficulties. Of particular concern is the management of radioisotopes. If it is possible to manage the process so that the radioisotopes are stripped from the process electrolyte before it enters nickel refining, process management will be greatly simplified.

Many of the metals involved in this process are, of themselves, toxic heavy metals. Discharge limits for these materials range from parts per billion to parts per million. Process operator exposures need to be minimized. Similarly, an effective strategy for waste minimization and stream recycle will have to be developed.

Several new process geometries and operating methods could enhance process safety if they can be adapted to nickel-based systems. These include flow-through hollow cathode geometries, which minimize process liquid volumes, and continuous metal production processes, such as the CLEAR copper recovery technology. A CLEAR-type process could minimize operator exposure by continuously producing and removing finely divided metal. Both types of processes have been demonstrated, but we could not find a literature record of their use in nickel electrorefining. However, minimization of process volume would reduce the amounts of chloride and chorine as well as minimize both cost and potential hazard.

\section{Research Needs}

Although bench-scale evaluations are starting, the literature research has shown several areas where research could produce effective improvements in existing commercial nickel refining processes. Several areas where research is needed to evaluate process parameters and probable performance were also apparent. It is expected that, in any DOE-facilities process, scrap nickel will be dissolved, and the resultant nickel solution will be extracted to remove $\mathrm{U}$, Tc, and Co. If necessary, solid-supported extractants or ion exchange will be used to remove trace contaminants, including ${ }^{234} \mathrm{Th},{ }^{234} \mathrm{~Pa},{ }^{137} \mathrm{Cs},{ }^{239} \mathrm{Pu}$ (trace), ${ }^{99} \mathrm{Tc}$, and ${ }^{237} \mathrm{~Np}$ (trace). Purified nickel electrolyte will flow to the refining process. If, as expected, an electrolytic process is used, nickel cathodes and chlorine gas will be produced in the cells. Nickel metal will be removed for use and the chlorine will be recycled to nickel scrap dissolution.

New process development should reflect both the active concerns of the user, DOE, and the best of current process technology. This implies a fully integrated process. Operating experience with nickel chloride, the most effective electrolyte system, is limited to a few years in one major facility. With a nitrate-based electrowinning facility, operating experience is limited to short-term pilot operations. Bench and pilot experiments to permit evaluation of cell and electrolyte systems tailored to DOE facility scrap and to proposed contaminant removal systems are needed to provide a basis for process evaluation. The evaluations should be detailed enough to provide a basis for understanding mass, energy, and heat flows.

Evaluation of the interactions between radionuclide removal or concentration processes and the electrolytic process is also needed. For example, the effect of agents, such as thiocyanate, typically used to complex ${ }^{60} \mathrm{Co}$ or ${ }^{99} \mathrm{Tc}$ during solvent extraction, within the 
electrolyte and the electrolytic cell has not been evaluated. Complexing agents and their breakdown products could have a major impact on cell operations because they could alter the transport and deposition of metals within the cell. Solvent breakdown products may also pose operating challenges. 


\section{Conclusions}

Development of a process for recovery of nickel in metal scrap from first generation diffusion plants could make more than 200,000 tons of this strategic metal available for domestic use. This technology could also significantly decrease DOE legacy wastes. Process developments are required because diffusion plant scrap is contaminated with small amounts of (predominantly depleted) $\mathrm{U}$ and with trace amounts of ${ }^{60} \mathrm{Co},{ }^{137} \mathrm{Cs},{ }^{237} \mathrm{~Np}$ (trace), ${ }^{284} \mathrm{~Pa},{ }^{39} \mathrm{Pu}$, ${ }^{99} \mathrm{Tc}$, and ${ }^{234} \mathrm{Th}$. With the exception of cobalt, these materials are not commonly associated with nickel and conventional refining processes have not been developed to remove them. De minimus standards for radiological contaminants in nickel, if adopted, are likely to be strict.

A variety of processes for nickel refining, including electrowinning, electrorefining, ammonia leaching, and the carbonyl process, have been used at industrial scale. Although each process technology has advantages and disadvantages, incorporation of aqueous separations into electrolytic processes is simplified because they involve dissolving and replating nickel. Process disadvantages include the need to physically manipulate nickel electrodes and the precipitation or codeposition of unremoved radiological contaminants. It may also be possible to adapt the carbonyl or ammonia leach processes for nickel scrap decontamination. These processes are highly automated and fully enclosed. Although nickel carbonyl is a highly toxic material, Inco's nickel carbonyl plants have operated safely for decades. Although the equipment for all four processes is different, all require roughly the same process area, 1 to 4 acres, and have modest process energy requirements.

A variety of techniques for the removal of specific radiological contaminants have been developed. Many of these have been used to prepare small samples for analysis. No single process or preparative method capable of removing all expected radiological components was reported. However, some solvent extractants and ion exchangers were common to several preparative methods. This indicates the possibility of development of processes which could remove or concentrate more than one radiological component. Integration and concurrent optimization of process and separations technologies remains the major process challenge. 


\section{References}

Bale, R. A., and E. T. Chapman. 1986. Inco's pressure carbonyl refining of nickel. In Proceedings of the 25th Annual Conference of Metallurgists, pp. 532-551. Montreal, Quebec: Canadian Institute of Mining and Metallurgy.

Barreta, L. G. 1980. Hydrolytic and radiolytic degradation of TBP in TBP $30 \% \mathrm{~V} / \mathrm{V}$ dodecane $/ \mathrm{UO}_{2}\left(\mathrm{NO}_{3}\right)_{2} \cdot \mathrm{HNO}_{3} \cdot \mathrm{H}_{2} \mathrm{O}$ systems. Universidade Federal do Rio de Janeiro report INISMF-6775.

Boldt, J. R., Jr. 1967. The winning of nickel. Toronto: Longmans Canada Limited.

Bonnesen, P. V.; Moyer, B. A.; Armstrong, V. S.; Haverlock, T. J.; and Sachleben, R. A. Removal of technetium from alkaline waste media by a new solvent extraction process. Presented at the American Chemical Society Symposium on Emerging Technologies in Hazardous Waste Management, 19-21 September 1994, Atlanta GA.

Caletka, R.; Hausbeck, R., and Kriven, V. 1986. Extraction of molybdenum, tungsten, and technetium with polyurethane foam and with cyclic polyether from thiocyanate/hydrochloric acid medium. Talanta 33(4): 315-320.

Cartledge, G. H. 1971. Free energies of formation of hydrous oxides of technetium in its lower valencies. Journal of the Electrochemical Society 118(2): 231-236.

Chaiko, D. J.; Vojta, Y.; and Takeuchi, M. 1993. Extraction of technetium from simulated Hanford tank wastes. Argonne National Laboratory report ANL/CMT/CP-80775.

Chaudhary, A. J. 1990. Added-value chemicals from secondary and low-grade primary sources. Doctoral dissertation, the City University, London.

Conard, B. 1994. Personal communication.

Demarthe, J. M.; Gandon, L.; and Goujet, M. 1983. Hydrometallurgical method for treating nickel mattes. Canadian patent 1,142,130.

Diamond, H.; Sabau, C. S.; Horwitz, E. P.; Vandergrift, G. F.; and Mason, G. W. 1979. Di-n-amyl-namylphosphonate and tricaprylmethylammonium nitrate as potential extractants for reprocessing Th-U fuels. Argonne National Laboratory report ANL-79-85/HDM.

Diamond, R. M., and D. C. Whitney. 1966. Resin selectivity in dilute to concentrated aqueous solutions. In Ion Exchange, ed. J. A. Marinsky, pp. 277-351. New York: Marcel Dekker.

Ejaz, M., and A. M. Mamoon. 1988. Studies on the extraction of technetium from thiocyanate solutions in mineral acids. Journal of Radioanal. Nucl. Chem. 125(2): 419-430.

Ettel, V. A.. 1983. Aqueous electro-refining and winning of metals - present technology and its limitations. In Electrochemistry research needs for mineral and primary materials processing, $\mathrm{T}$. J. O'Keefe and J. W. Evans, eds., pp. 185-192. U.S. Bureau of Mines Publication PB84-192905.

Fabre, M. 1980. Influence of dibutylphosphoric acid on kinetics of hexavalent uranium transfer, from a nitric solution, in a tributyl phosphate solution diluted to $30 \%$ with dodecane. CEA Centre d'Etudes Nucleaires de Fontenay-aux-Roses report CEA-R-5045/HDM.

Faris, J. P., and R. F. Buchanan. 1964. Anion exchange characteristics of elements in nitric acid medium. Analytical Chemistry 36: $1157-1158$.

Flett, D. S., and J. W. Evans. 1983. Non-conventional cells for electrowinning from aqueous solutions. In Electrochemistry research needs for mineral and primary materials processing, T. J. O'Keefe and J. W. Evans, eds., pp. 39-49. U.S. Bureau of Mines Publication PB84-192905. 
Foster, R. E.; Maeck, W. J.; and Rein, J. E. 1967. Liquid-liquid extraction of technetium as tetrapropylammonium salt and spectrophotometric determination as the thiocyanate complex. Analytical Chemistry 39(6): 563-566.

Freitas, R. F. deS. 1982. Thermodynamics of the extraction of uranium and nitric acid from an aqueous solution with TBP/diluent.E. I. Du Pont de Nemours and Co. report DP-TR-69.

Fujita, T.; Sekine, T.; Hiraga, H.; Yoshihara, K.; Mutalib, A.; Alberto, R.; and Kim, J. I. 1993. Determination of Tc by laser induced photoacoustic spectroscopy coupled with a wavelength shifter. Radiochimica Acta 63: 45-47.

Googin, J. M.; Harper, W. L.; Phillips, L. R.; and Postma, F. W. 1962. Evaluation of diethers as uranium extractants. Y-12 Plant report Y-1408.

Gorski, B.; Gruendig, M.; and Richter, M. Development of an extraction process for technetium and palladium recovery from nuclear fuel reprocessing waste solution. Part 1. Extraction of technetium and palladium with tri-n-octylamine. Isotopenpraxis 20(3): 93-97.

Gorski, B.: Richter, M.; and Hennrich, M. 1982. Recovery of technetium and palladium from nuclear fuel reprocessing solutions. East German patent 154970.

Griffith, W. L.; Jasney, G. R.; and Tupper, H. T. 1952. The extraction of cobalt from nickel in a pulse column. Massachusetts Institute of Technology Engineering Practice School report K-972.

Grychowski, P.; Mikulski, J.; Moravets, Ya.; Shara, V.: and Shourkova, L. 1981. Infrared studies on complexes between octaethyltetraamidepyrophosphate (OETAPP) and uranyl salts. Institute of Nuclear Physics, Kracow, report INP-1143/C.

Hanif, I.; Hasany, S. M.; and Ejaz, M. 1977. Extraction of elements from aqueous thiocyanate solutions by 2-hexylpyridine in benzene. Radiochemica Acta 24(1): 19-20.

Hanulik, J. 1989. Process for decontaminating radioactively contaminated metallic materials. U.S. patent 4,828,759.

Horwitz, E. P., and W. W. Delphin. 1979. Method for recovering palladium and technetium values from nuclear fuel reprocessing waste solutions. U. S. Department of Energy report PAT-APPL865347.

Horwitz, E. P.; Delphin, W. H.; and Mason, G. W. 1979. Method for the recovery of actinide elements from nuclear reactor. U. S. Department of Energy report PAT-APPL-865 346.

Hurst, F. J. 1976. Separation of cobalt from nickel in ammonium-ammonium carbonate solutions using pressurized ion exchange. Hydrometallurgy 1: 319-338.

Hyder, M. L.; Perkins, W. C.; Thompson, M. C.; Burney, G. A.; and Russell, E. R. 1979. Processing of irradiated, enriched uranium fuels at the Savannah River Plant. E. I. Du Pont de Nemours and Co. Savannah River Laboratory report DP-1500/HDM.

Jankowska, M.; Kulawik, J.; and Mikulski, J. 1980. Extraction of uranium (6), thorium (4), hafnium (4), and iron (3) in system octaethyltetraamidopyrophosphate (OETAPP) - electrolyte. Institute of Nuclear Physics, Kracow report INP-1083/C.

Johnson, J. S., Jr.; Clark, R. J.; and Westmoreland, C. G. 1984. An evaluation of retardation parameters for nuclide migraton in geologic media: technetium. In Chemistry Divison Annual Report for period ending Jan 31, 1984. pp. 183-188. Oak Ridge National Laboratory report ORNL-6037.

Johnson, J. S. Jr.; Westmoreland, C. G.; Sweeton, F. H.; Kraus, K. A.; Hagaman, E. W.; Eatherly, W. P.; and Child, H. R. 1986. Modificaiton of cation-exchange properties of activated carbon by treatment with nitric acid. Journal of Chromatography 354: 231-248.

Kang, Y. H.; Kim, J. D.; and Kim, K. H. 1990. Study of ion separation through solid-supported liquid membrane. Korea Atomic Energy Research Institute report KAERI/RR-835/89

Konno, T., and J. Hidaka. 1989. Chemistry of Tc complexes. Kagaku (Kyoto) 44(3): 202-203. 
Korkisch, J.; Steffan, I.; and Navratil, J. D. 1981. Recovery of uranium by extraction with polyurethane foam. Rocky Flats Plant report RFP-3254.

Kraus, K. A., and F. Nelson. 1955. Anion exchange studies of the fission products. In Proceedings of the International Conference on the Peaceful Uses of Atomic Energy I, Vol. 7, pp. 113-136. New York: United Nations.

Kraus, K. A., and F. Nelson. 1958. Metal separation by ion exchange. In Symposium on Ion Exchange and Chromatography in Analytical Chemistry, pp. 27-57. American Society for Testing Materials special technical publication 195. (See esp. Fig 11.)

Kraus, K. A.; Nelson, F.; Clough, F. B.; and Carlston, R. C. 1955. Anion exchange studies. XVI. Adsorption from lithium chloride solutions. Journal of the American Chemical Society 77: 1391.

Kraus, K.A.; Phillips, H. O.; Carlson, T. A.; and Johnson, J. S., Jr. 1958. Ion exchange properties of hydrous oxides. In Proceedings of the Second United Nations International Conference on the Peaceful Uses of Atomic Energy Geneva Vol. 28, pp. 3-16. New York: United Nations.

Kraus, K.A.; Phillips, H. O.; and Nelson, F. 1962. Some applications of radioisotopes in physical chemistry - two phase equilibria and packed-column techniques. In Proceedings of the 1960 IAEA Copenhagen Conference on "Radioisotopes in the Physical Sciences and Industry", Vol. III, pp. 387-406. Vienna: International Atomic Energy Agency.

Kuck, P. H. 1991. Nickel. In Minerals yearbook, pp. 1029-1056. Washington DC: Government Printing Office.

Lahoda, E. J.; Eckhardt, D. A.; and Grover, D. L. 1982. Electrolytic decontamination. U. S. patent $4,318,786$.

Lazic., S., and Z. Vukovic. 1991. Removal of ${ }^{137} \mathrm{Cs}$ and ${ }^{60} \mathrm{Co}$ from real radioactive waste solution by precipitation-flocculation method. Radioactive Waste Management and the Nuclear Fuel Cycle 15(4): 241-250.

Maeck, W. J.; Kussy, M. E.; and Rein, J. E. 1963. Adsorption of the elements on ionrganic ionexchangers from nitrate media. Analytical Chemistry 35: 2086-2090.

Mailen, J. C. 1981. Interpretation of the extraction mechanism of the Purex and Thorex processes from kinetics data. Oak Ridge National Laboratory report CONF-810520-2/HDM.

Meyer, R. E., and W. D. Arnold. 1991. The electrode potential of the Tc(IV)-TC(VII) couple. Radiochimica Acta 55: 19-22.

Meyer, R. E.; Arnold, W. D.; Case, F. I.; and O'Kelley, G. D. 1989. Thermodynamics of technetium related to nuclear waste disposal. Oak Ridge National Laboratory report ORNL-6503.

Meyer, R. E.; Arnold, W. D.; Case, F. I.; and O'Kelley, G. D. 1991. Solubilities of Tc(IV) oxides. Radiochimica Acta 55: 11-18.

Murray, A. P., and T. S. Snyder. 1985. Decontamination using electrolysis. U. S. patent 4,537,666.

Nagel, C. J., and R. D. Bach. 1994. Method of indirect chemical redution of metals in waste. U. S. patent 5,358,549.

Nashner, S. 1955. Refining at Fort Saskatchewan. The Canadian Mining and Metallurgical Bulletin 48(519): 396-410.

Nelson, F., and D. C. Michelson. 1966. Ion-exchange procedures. IX. Cation exchange in $\mathrm{HBr}$ solutions. Journal of Chromatography 25: 414-441.

Nelson, F.; Murase, T.; and Kraus, K. A. 1964. Ion exchange procedures. I. Cation exchange in concentrated $\mathrm{HCl}$ and $\mathrm{HClO}_{4}$ solutions. Journal of Chromatography 13: 503-535.

Nelson, F., and K. A. Kraus. 1979. Ion-exchange procedures. X. Cation exchange in concentrated $\mathrm{HClO}_{4}-\mathrm{HCl}$ solutions. Journal of Chromatography 178: 163-181.

Orebaugh, E. G., and R. C. Propst. 1980. Electrolytic production of uranous nitrate. E. I. Du Pont de Nemours and Co. Savannah River Laboratory report DP-1549/HDM. 
Orth, D. A.; Martin, W. H.; and Pickett, C. E. 1983. Enriched uranium processing with 7-1/2\% TBP. E. I. Du Pont de Nemours report DP-MS-83-1.

Palmer, D. A., and R. E. Meyer. 1981. Adsorption of technetium on selected inorganic ion-exchange materials and on a range of naturally occurring minerals under oxic conditions. Journal of Inorganic and Nuclear Chemistry 43: 2979-2984.

Peacock, R. D. Technetium. In Comprehensive inorganic chemistry, Vol. 3, ed. J. C. Bailar, Jr.; H. J. Emeleus; R. Nyeholm; and A. F. Trotman-Dickenson, pp. 877-903. Oxford, UK: Pergamon Press, Ltd.

Petrich, T., and Z. Kolarik. 1981. 1981 Purex distribution data index. Kernforschungszentrum Karlsruhe G. m. b. H. Inst. fuer Heisse Chemie report KFK-3080.

Pruett, D. J. 1981. Solvent extraction of heptavalent technetium by tributyl phosphate. Oak Ridge National Laboratory report CONF-810520-4/HDM.

Pushlenkov, M. F., and V. V. Zimenkov. 1979. Investigation of limiting stage of uranium extraction with tributyl phosphate from nitric acid solutions in centrifugal extractor. Radievyi Inst., Leningrad, report RI-100/HDM.

Rimshaw, S. J., and F. N. Case. 1980. Volatilities of ruthenium, iodine, and technetium on calcining fission product nitrate wastes. Oak Ridge National Laboratory report CONF-801038-4/HDM.

Rochon, A., and M. Nowak. 1979. Influence of the temperature on re-extraction of uranium from irradiated solutions of tributylphosphate in n-dodecane. Institute of Nuclear Research, Warsaw report INR-1808/22/C/B.

Sasaki, T.; Kobayashi, T.; and Wada, K. 1986. Electrolytic decontaminaton process and process for reproducing decontaminating electrolyte by electrodeposition and apparatuses therefore. U. S. patent 4,615,776.

Shiao, S.-Y.; Egozy, Y.; and Meyer, R. E. 1981. Adsorption of Cs(I), Sr(II), Eu(III), Co(II), and Cd(II) by $\mathrm{Al}_{2} \mathrm{O}_{3}$. Journal of Inorganic and Nuclear Chemistry 43: 3309-3315.

Snyder, T. S., and A. P. Murray. 1988. Electrolytic decontamination apparatus and encapsulation process. U. S. patent $4,792,385$.

Snyder, T. S.; Gass, W. R.; Worcester, S. A.; and Ayers, L. J. 1992. Decontamination of radioactive metals. U. S. patent 5,156,722.

Snyder, T. S., and G. A. Whitlow. 1991. Integrated decontamination process for metals. U. S. statutory invention registration $\mathrm{H} 970$.

Spitsyn, V. I., and coworkers. 1964. Chemical and electrochemical properties of technetium in aqueous solutions. In Proceedings of the 3rd International Conference on Peaceful Uses of Atomic Energy, pp. 561-570. Oak Ridge National Laboratory translation ORNL-tr-4868.

Stensholt, E. O.; Zachariasen, H.; Lund, J. H.; and Thornhill, P. G. 1988. Recent improvements in the Falconbridge nickel refinery. In Extractive metallurgy of nickel and cobalt, ed. G. P. Tyler and C. A. Landholt. London: The Metallurgical Society.

Tien, J. K., and T. E. Howson. 1981. Nickel and nickel alloys. In Kirk-Othmer: Encyclopedia of chemical technology, third edition, pp. 787-801. New York: John Wiley and Sons.

Walker, C. R., and B. W. Short. 1979. Radiochemical procedure specific for the determination of protactinium-231. U.S. Department of Energy report CONF-791049-S.

Williams, D. F.; O'Kelley, G. D.; Knauer, J. B.; Porter, C. E., and Wiggins, J. T. 1993. Recovery and purification of nickel-63 from HFIR-irradiated targets. Oak Ridge National Laboratory report TM-12399.

Windt, N. F., and J. L. Williams. 1983. Method for decontamination of nickel-fluoride-coated nickel containing actinide-metal fluorides. U.S. patent 4,421,556. 